\title{
The Evolution of the 2012 Great Lakes Water Quality Agreement
}

\author{
by
}

Chris B. Fryefield

\begin{abstract}
A thesis submitted
in partial fulfillment of the requirements

for the degree of

Master of Science (Natural Resources and Environment) / Juris Doctor

University of Michigan
\end{abstract}

May 2013

Thesis Committee:

UM SNRE Advisor: Professor Mike Wiley

UM Law Advisor: Professor Noah Hall 



\begin{abstract}
:
This thesis considers the 2012 Great Lakes Water Quality Agreement between the United States and Canada from the perspectives of both ecological science and law and policy. Since the signing of the first GLWQA in 1972, ecological issues affecting the Great Lakes have been addressed by multiple overlapping regulatory agencies and stakeholders. Despite bilateral and unilateral efforts at all jurisdictional levels to control environmental degradation, problems like algal blooms, disease outbreaks, and loss of wetlands continue to damage the Lakes today. The GLWQA, as non-binding international "soft law", may or may not be the proper instrument to address these resurgent problems. In this thesis, changes in the GLWQA over time are compared to the most pressing environmental crises in the Lakes today in an attempt to determine how the Agreement practically functions in the complex and interconnected realm of environmental law and policy. The ecological science and hydrologic scope of the 2012 Agreement has been expanded to cover multiple new issues and pathways of environmental degradation. The soft law tone of the Agreement, however, remains general and somewhat vague in nature; undercutting the efficacy of its provisions. The 2012 GLWQA has the potential to be a very beneficial tool for coordination and cooperation in addressing environmental problems in the Great Lakes. Whether that potential will be fulfilled or not, however, is ultimately up to the many stakeholders who address the ecological issues on the ground.
\end{abstract}




\section{ACKNOWLEDGMENTS:}

I would very much like to thank,

My thesis advisors, Professor Mike Wiley* and Professor Noah Hall**.

The University of Michigan Law School and the School of Natural Resources and Environment.

The Women in Science and Engineering/Sweetland Center Master’s Thesis Writing Group.

* Michael J. Wiley, Ph.D., Theodore Roosevelt Professor of Ecosystem Management, Professor of Aquatic Ecology at the School of Natural Resources and Environment, University of Michigan.

** Noah D. Hall, J.D., Associate Professor of Law at Wayne State University Law School, Visiting Professor at the University of Michigan Law School. 


\title{
TABLE OF CONTENTS:
}

\author{
Abstract \\ Acknowledgments \\ Table of Contents \\ Introduction \\ Section 1: Law and Policy \\ A. History of Bilateral Water Management \\ i. The Boundary Waters Treaty \\ ii. The 1972 GLWQA \\ iii. Previous Revisions of the GLWQA
}

B. The 2012 Great Lakes Water Quality Agreement

C. Additional Applicable Transboundary Law

Section 2: Ecological Issues

A. Pollution

i. Toxics

ii. Disease Pollutants

iii. Nutrient Pollution

B. Habitat Loss

i. Coastal Communities and Wetlands Loss

ii. Cold Oligotrophic Lake Habitat Loss

iii. Benthic Habitat Degradation

C. Aquatic Invasive Species

i. Invertebrates

ii. Fish

iii. Plants

iv. Risk of Future Invasions

Section 3: Comparison and Conclusions

A. Soft Law and Conflicting Management Strategies

B. New Priorities and Old Challenges

Conclusion 


\section{INTRODUCTION:}

This thesis is an examination of the recently signed 2012 Great Lakes Water Quality Agreement (GLWQA) between the United States and Canada. The central goal is to compare the bilateral agreement and the major environmental issues facing the Great Lakes to determine if any of the management strategies in the GLWQA have been particularly successful in maintaining the quality of these water systems. If the critical ecological problems and the solutions offered by the Agreement are more than slightly mismatched with the most critical ecological issues, it is unlikely to prove an effective addition to the legal management of this important freshwater system.

The Laurentian Great Lakes is a very important hydrologic system that forms part of the border between the United States and Canada. The Great Lakes stores the largest volume of liquid freshwater in the world. The Lakes and their tributaries are critical to the health, economy, agriculture, and recreation of the citizens of both nations who live near them. As such, it was recognized early on that the Great Lakes would require interstate management to maintain ecosystem health and essential ecosystem services. Beginning with an initial Boundary Waters Treaty in 1909, the two nations have continued to update and expand the relevant domestic and international law to govern the use of and protect the value of this unique water resource. Despite these legal provisions environmental problems like pollution, loss of habitat, and invasive species have continued to plague the Lakes. Additionally, nations around the world look to the Boundary Waters Treaty and the GLWQA as an example of effective bilateral management of a critical and threatened resource. Determining how successful the most recent version of the Agreement is will be important, not just for the Great Lakes stakeholders in the United States and Canada, but for any others who look to the GLWQA for guidance in managing their own international resources.

To that end, this thesis discusses, first, the history and development of the law surrounding the interstate management of the Great Lakes system. The 2012 GLWQA is placed in its appropriate legal context with a brief overview of other legal mechanisms that inform management of the transboundary waters. The second part of this thesis identifies the most important and pressing environmental issues currently affecting the ecological and hydrological health of the Great Lakes system. Finally, the articles of the 2012 GLWQA are contrasted with the key issues identified in Section 2, and major gaps and lapses in the legal protections are noted and discussed. From this analysis may be drawn a more informed concept of the true efficacy of the current GLWQA, as well the identification of potential areas that may require additional protection. 


\section{SECTION 1: LAW AND POLICY}

This Section considers the history of the legal measures taken bilaterally by the United States and Canada to manage the Great Lakes water system. The Section begins with a discussion of the 1909 Boundary Waters Treaty, and then discusses the evolution of the Great Lakes Water Quality Agreement from the original version to the most recently signed. It concludes with a brief overview of some of the many additional laws and policies that also govern the management of the Great Lakes.

\section{A. History of Bilateral Water Management}

\section{i. The Boundary Waters Treaty}

In 1909 the United States and Great Britain, on behalf of the Dominion of Canada, signed a Treaty "relating to boundary waters between the United States and Canada”. ${ }^{1}$ This Boundary Waters Treaty was intended to "prevent disputes" and "settle all questions" between the United States and Canada on the use and management of the waters that formed part of the border. ${ }^{2}$ The Boundary Waters Treaty was very much a product of its time, and as such its primary focus was on maintaining water quantity in the boundary waters. ${ }^{3}$ The Treaty defined the boundary waters themselves as "the waters from main shore to main shore of the lakes and rivers... along which the international boundary between the United States and the Dominion of Canada passes” but not including their tributary waters or any discussion of groundwater. ${ }^{4}$ The Articles of the Boundary Waters Treaty addressed the major issues of these waters at the time; rights of navigation, control over use and diversion of water, protection of quality and quantity of water, and jurisdiction. ${ }^{5}$ Despite the primary focus of the Treaty on water quantity, Article IV contains a provision that "the waters herein defined as boundary waters and waters flowing across the boundary shall not be polluted on either side to the injury of health and property on the other". ${ }^{6}$

The Treaty also established the International Joint Commission (IJC) to address future interstate water issues. ${ }^{7}$ The IJC is composed of six practitioners - three from the United States and three from Canada. ${ }^{8}$ The IJC, according to Article X of the Boundary Waters Treaty, may hear disputes and provide reports on issues between the United States and Canada. The IJC may be considered to be a quasijudiciary body that, ideally, provides impartial advice to both nations. ${ }^{9}$ However, the Boundary Waters

\footnotetext{
${ }^{1}$ Treaty between the United States and Great Britain relating to boundary waters between the United States and Canada. U.S. Statutes at Large 36 Stat. 2448, Potomac Publishing Co., Inc.

${ }^{2} I d$. in Preamble.

${ }^{3}$ J. Owen Saunders, Law and the Management of the Great Lakes Basin, Canadian Water Resources Journal, 25:2, 209-242 (2000).

${ }^{4}$ Boundary Waters Treaty. in Preliminary Article.

${ }^{5} \mathrm{Id}$.

${ }^{6} I d$. Article IV.

${ }^{7}$ Id. Article VII.

${ }^{8}$ Id. Article VII; see also The International Joint Commission, Who We Are, available at http://www.ijc.org/en/background/ijc_cmi_nature.htm (last visited October 31, 2012).

${ }_{9}^{9}$ L. H. Legault, Chairman, Canadian Section,IJC, Address to the Canada - United States Law Institute, Case Western Reserve University School of Law: The Roles of Law and Diplomacy (April 14, 2000)
} 
Treaty only allows for the presentation of a dispute to the IJC if both countries agree that it should be so heard. ${ }^{10}$ It should be noted here that no such dispute has ever been referred to the IJC under Article X. ${ }^{11}$ An additional key element of the IJC is its requirement that each commissioner rely on their "professional capacity and expertise" rather than on behalf of their particular government. ${ }^{12}$ This operating principle aims to make the IJC independent, but may cause conflicts of interest for the commissioners in carrying out their duties. ${ }^{13}$

The Boundary Waters Treaty of 1909 remains the fundamental basis for interstate water management between the United States and Canada. As a treaty, it is the supreme law of the land in the United States by virtue of the U.S. Constitution, Article VI. ${ }^{14}$ In Canada, the Boundary Waters Treaty was implemented domestically by the International Boundary Waters Treaty Act of $1911 .{ }^{15}$ Although the initial treaty has been expanded through other agreements, protocols, and domestic implementation and management in both nations since 1909, the Boundary Waters Treaty remains the principal document underlying those other laws. The GLWQAs, for example, contain language specifying that the further agreements shall not be construed as to diminish the obligations of the parties under the Boundary Waters Treaty. ${ }^{16}$ The 2012 GLWQA retains language from the 1978 version stating the governments of the United States and Canada reaffirm "in a spirit of friendship and cooperation, the rights and obligations of both countries under the Treaty relating to the Boundary Waters and Questions arising along the Boundary between Canada and the United States...and, in particular, the obligation not to pollute boundary waters". ${ }^{17}$ The Boundary Waters Treaty provides legal support for the more specific objectives and procedures outlined in the future GLWQAs.

\section{ii. The 1972 Great Lakes Water Quality Agreement}

One of the expansions of the Boundary Waters Treaty is the Great Lakes Water Quality Agreement. The GLWQA is a protocol between the United States and Canada that works on identifying and establishing methods for addressing the most pressing environmental issues in the Great Lakes hydrologic system. ${ }^{18}$ The GLWQA provides the two nations with an ongoing mechanism to coordinate

available at http://www.ijc.org/php/publications/html/legault_april.html [hereinafter Legault, Law and Diplomacy].

1036 Stat. 2448.

${ }^{11}$ Legault, Law and Diplomacy, supra note 9; Botts \& Muldoon, infra at 12.

${ }^{12}$ Lee Botts \& Paul Muldoon, Evolution of the Great Lakes Water Quality Agreement at 9, Michigan University Press 2005, quoting the Boundary Waters Treaty.

${ }^{13} \mathrm{Id}$.

${ }^{14}$ U.S. Const. art. VI, cl 2.

${ }^{15}$ The International Boundary Waters Treaty Act, R.S.C., 1985, c. I-17, available at http://laws.justice.gc.ca/eng/acts/I-17/page-1.html, from the Canadian Justice Department website. See also Origins of the Boundary Waters Treaty, International Joint Commission, available at http://www.ijc.org/en/Origins of the Treaty (last visited February 22, 2013).

${ }^{16}$ Great Lakes Water Quality Agreement, Article XII, U.S-Canada, Apr. 15, 1972, 23.1 U.S.T. 301.

${ }^{17}$ Great Lakes Water Quality Agreement, 1978 appendix, in the Protocol of 2012. (Treaty title italicized in original).

${ }^{18}$ Great Lakes Water Quality Agreement, Preamble, U.S-Canada, Apr. 15, 1972. 
and cooperate on the management of waters that are extremely important to the economic and environmental health of residents of both countries.

Since the 1960s, reports on the Lakes had been identifying problems with water quality and quantity (for example, eutrophication and pollution in Lake Erie) that needed to be addressed further by both countries. ${ }^{19}$ The late 1960s and early 1970s saw major growth in the citizen environmental movement in both the United States and Canada, and the establishment of the U.S. Environmental Protection Agency and the Canadian Department of the Environment. ${ }^{20}$ In 1970 the IJC published a report that outlined recommendations for further work to restore and maintain the Lakes. ${ }^{21}$ According to the IJC, "the Commission's final report in 1970 concluded that municipal and industrial pollution indeed was occurring on both sides of the boundary to the injury of health and property on the other side" in violation of Article IV of the Boundary Waters Treaty. ${ }^{22}$ To address these issues a joint working group was formed that negotiated the first GLWQA. ${ }^{23}$

The original GLWQA was a water management (primarily water quality and pollution focused) agreement initially signed by Prime Minister Pierre Trudeau and President Richard Nixon in Ottawa on April 15, 1972. The stated purpose was to "restore and enhance water quality in the Great Lakes System". ${ }^{24}$ The Preamble of the Agreement also stated that the Parties were "[c]onvinced that the best means to achieve improved water quality in the Great Lakes System is through the adoption of common objectives, the development and implementation of cooperative programs and other measures, and the assignment of special responsibilities and functions to the International Joint Commission”. ${ }^{25}$

The 1972 Agreement was relatively short, consisting of thirteen articles and annexes. The Agreement set basinwide water quality objectives for the Lakes, and included commitments by the party nations to implement and monitor municipal and industrial pollution control programs. ${ }^{26}$ Article II listed the general water quality objectives of the Agreement. The language of these objectives was aspirational, broadly drawn, and more descriptive than practical. For example, Article II stated that waters of the Lakes should be "free from substances that enter the waters as a result of human activity and that will settle to form putrescent or otherwise objectionable sludge...free from nutrients entering the waters as a result of human activity in concentrations that create nuisance growths of aquatic weeds and algae" ${ }^{27}$ Article III adopted the more specific and practical water quality objectives listed in Annex 1 of the Agreement, and noted that the objectives were minimums and not maximums - that further improvements in water quality could and should be set above those of the current Agreement. ${ }^{28}$

\footnotetext{
${ }^{19}$ Botts \& Muldoon, supra at 13.

${ }^{20} I d$.

${ }^{21}$ International Joint Commission of Canada and the United States, "Pollution of Lake Erie, Lake Ontario, and the International Sections of the St. Lawrence River", 1970.

${ }^{22}$ IJC, “A Guide to the Great Lakes Water Quality Agreement”, available at http://www.ijc.org/en/activitiesX/consultations/glwqa/guide 3.php\#1972.

${ }^{23}$ Botts \& Muldoon, supra at 15.

${ }^{24}$ The Great Lakes Water Quality Agreement, Article II, U.S.-Canada, April 15, 1972.

${ }^{25} I d$. at Preamble.

${ }^{26} I d$.

${ }^{27}$ Id. at Article II.

${ }^{28}$ Id. at Article III.
} 
Other Articles in the 1972 Agreement made the broad water quality goals more achievable by putting the Parties on the same page for setting standards, managing water quality issues, and consulting and reviewing in concert. ${ }^{29}$ To assist the IJC in its special responsibilities for bilateral management, mentioned in the Preamble, the Agreement established in Article VIII the Great Lakes Water Quality Board (composed of senior representatives of the federal, state and provincial governments) and the Research Advisory Board (composed of research managers). ${ }^{30}$

The first GLWQA explicitly endorsed its own process of ongoing review and revision in Article $\mathrm{X}$, following the Biennial Reports of the IJC, which set up the future system of amendments and expansions of this initial agreement. This Article directs the Parties to perform a "comprehensive review of the operation and effectiveness of this Agreement following every third biennial report of the Commission". ${ }^{31}$ Article X, as well as the periodic reviews of the state of the Great Lakes done by the IJC (and later by other organizations) has made the evolution of the Agreement to keep up with changes in science and policy possible.

\section{iii. Previous Revisions of the Great Lakes Water Quality Agreement}

There have actually been a series of GLWQAs since the original was signed in 1972. The GLWQA was renewed in 1978, and amended by additional Protocols in 1983 and $1987 .{ }^{32}$ At the time of writing the 2012 version of the GLWQA is the current version.

After the establishment of the first GLWQA, multiple meetings and reports were given on the ongoing process of binational cooperation on cleaning up the Lakes. The Research Advisory Board issued annual reports to the IJC, and the IJC also reported annually (later to be biennially) to the United States and Canadian governments. ${ }^{33}$ In 1977 there was a general review of the progress of the GLWQA in order to determine if a new agreement was necessary. Due to ongoing public concern about prominent ecological issues like eutrophication and hypoxia in Lake Erie, the agreement was renewed. ${ }^{34}$

The renewal of the GLWQA in 1978 reaffirmed the commitment of the Parties to cooperating on the water quality of the Great Lakes system. Some of the mechanisms for maintaining Great Lakes water quality were updated to reflect new recognized stressors and more modern scientific information. ${ }^{35}$ In the new version of Article IV the Parties admitted that, due to both human and natural processes, the objectives of the previous GLWQA were not being met. ${ }^{36}$ Additionally the Parties agreed to continue to

\footnotetext{
${ }^{29} I d$.

${ }^{30}$ IJC, “A Guide to the Great Lakes Water Quality Agreement”.

${ }^{31} 1972$ Great Lakes Water Quality Agreement, Article X.

${ }^{32}$ Great Lakes Water Quality Agreement, as Amended, U.S.-Canada, Nov. 22, 1978, 30 U.S.T. 1384;

Protocol on Great Lakes Water Quality, as Amended on October 16, 1987, Amending the 1978

Agreement Between the United States of America and Canada, U.S-Canada., Nov. 18, 1987. See also The International Joint Commission, Treaties and Agreements, available at http://www.ijc.org/rel/agree/quality.html, (last visited October 31, 2012).

${ }_{33}$ Botts \& Muldoon, supra at 48.

${ }^{34} \mathrm{Id}$. at 49.

${ }^{35}$ Great Lakes Water Quality Agreement, as Amended, U.S.-Canada, Nov. 22, 1978, 30 U.S.T. 1384.

${ }^{36} I d$. at Article IV (1) (e) and (f).
} 
consult on the specific objectives set for water quality in the Lakes, and to control pollutant loading rates for each lake basin so as to protect "the integrity of the ecosystem over the long term". ${ }^{37}$

One major update was the use of an "ecosystem approach" to management that appeared for the first time in this version of the GLWQA. Article I of the new Agreement now had a definition of the "Great Lakes Basin Ecosystem” as "the interacting components of air, land, water and living organisms, including humans". ${ }^{38}$ Article II, the new Purpose section, now committed the Parties to "restore and maintain the chemical, physical, and biological integrity of the waters of the Great Lakes Basin Ecosystem". ${ }^{39}$ Botts and Muldoon, writing about the history of the GLWQ Agreements, tie this new ecological vision for the Lakes to the expansion of the environmental movement in both the United States and Canada in the 1970s. ${ }^{40}$ In their opinion, "many members of the Great Lakes community have come to believe that the new language meant that the purpose of the Great Lakes Agreement is now restoration of ecological as the major goal, not just improved water chemistry through pollution control". ${ }^{41}$ Language in the Preamble of the 1978 Agreement supports this view: "restoration and enhancement of the boundary waters cannot be achieved independently of other parts of the Great Lakes Basin Ecosystem”. 42

In 1983 a supplement was added to the 1978 GLWQA to address phosphorous load reduction. Nutrient loading had been a concern in the Great Lakes basin, particularly in shallow Lake Erie, since the 1950s. ${ }^{43}$ The supplement added to Annex 3 - Control of Phosphorous of the 1978 GLWQA an expanded requirement to reduce the amount of phosphorous added to the Lakes system. ${ }^{44}$ The 1983 supplement added some new scientific information regarding the relation of land use to phosphorous introduction, and encouraged the countries to work further on reducing their load allocations and continue to monitor the water quality of the Lakes for further nutrient pollution problems. The phosphorous load reduction supplement's purpose was "to outline measures to fulfill the commitments undertaken pursuant to paragraph 3 of Annex 3 of the 1978 Great Lakes Water Quality Agreement which requires that: The Parties, in cooperation with the State and Provincial Governments, shall within eighteen months after the date of entry into force of this Agreement confirm the future phosphorous loads, and based on these establish load allocations and compliance schedules". ${ }^{45}$ Tables following this statement of purpose laid out the metric tonnes of phosphorous that could be loaded into the Lakes and the required reduction in overall phosphorous loading to meet water quality standards. It should be noted, however, that text in the footnotes to the tables would remind the reader that any "allocation of the phosphorous target loads

\footnotetext{
${ }^{37}$ Id. at Article IV (3).

${ }^{38} \mathrm{Id}$. at Article I (g).

${ }^{39} \mathrm{Id}$. at Article II.

${ }^{40}$ Botts \& Muldoon, supra at 57 (pointing out that many new environmental regulations and agencies were established in both countries during this period).

${ }^{41} I d$. at 67.

421978 Great Lakes Water Quality Agreement, as Amended, at Preamble.

${ }^{43}$ William Ashworth, The Late, Great Lakes: An Environmental History, Wayne State University Press, 1987.

${ }^{44}$ Phosphorous Load Reduction Supplement to the 1978 Great Lakes Water Quality Agreement, as Amended, at Annex 3. Available at http://www.ijc.org/rel/agree/quality.html\#ann3a.

${ }^{45}$ Id. at 1.
} 
between the two countries shall be consistent with the equal rights of both Parties in the use of their boundary waters". ${ }^{46}$

The Protocol of 1987 further amended the agreement of 1978. One key addition of the 1987 Protocol was the creation of the Binational Executive Committee, who took over monitoring and updating duties from the existing Water Quality Board. ${ }^{47}$ The "State of the Lakes” reports, for example, are no longer issued by the Water Quality Board, but instead are written by the State of the Lakes Ecosystem Conference, which is directed by the Executive Committee. ${ }^{48}$ Another important addition in the 1987 version of the GLWQA was the creation of Remedial Action Plans and Lakewide Management Plans to involve "local governments and other stakeholders" 49 . Those planning requirements for Areas of Concern in the Lakes (AOCs) continue in the latest version of the GLWQA. Additional annexes to the Agreement addressed new issues of ecological concern, including airborne toxics and contaminated sediments. ${ }^{50}$ The Amending Protocol, for example, states that the Parties recognize "the need for strengthened efforts to address the continuing contamination of the Great Lakes Basin Ecosystem, particularly by persistent toxic substances". ${ }^{51}$ The final list of annexes in the 1978 GLWQA, with the 1983 Supplement and the 1987 Protocol's additions, can be seen below in Fig. 1.

Figure 1: List of Annexes of the Revised 1978 Great Lakes Water Quality Agreement

\begin{tabular}{|l|l|l|}
\hline Annexes of the $\mathbf{1 9 7 8}$ GLWQA & Purpose \\
\hline Annex 1 & Specific Objectives & $\begin{array}{l}\text { Specific objectives to protect the "most sensitive } \\
\text { use". Long list of numerical and/or descriptive } \\
\text { water quality standards for chemical, physical, } \\
\text { microbiological and radiological pollutants. }\end{array}$ \\
\hline Annex 2 & $\begin{array}{l}\text { Remedial Action Plans and } \\
\text { Lakewide Management Plans }\end{array}$ & $\begin{array}{l}\text { Expands on the ecosystem approach by naming } \\
\text { damaged areas and giving guidelines to managers } \\
\text { for the creation of management plans and pollution } \\
\text { reduction. Plans for Areas of Concern (AOCs) and } \\
\text { Lakewide Management Plans. }\end{array}$ \\
\hline Annex 3 & Control of Phosphorus & $\begin{array}{l}\text { Reduction of phosphorous loading to maintain } \\
\text { aerobic conditions and remove nuisance algae. } \\
\text { Includes 1983 Supplement with total load and load } \\
\text { allocations. }\end{array}$ \\
\hline
\end{tabular}

\footnotetext{
${ }^{46} \mathrm{Id}$. at footnote to Table 1.

${ }^{47}$ Krantzberg, Gail, “The Ongoing Review of the Great Lakes Water Quality Agreement”, J. of Great Lakes Rsrch., 33(3) 699-703, (2007).

${ }^{48} \mathrm{Id}$.

491978 Great Lakes Water Quality Agreement, as Amended, at Annex 2; see also Botts \& Muldoon, supra at 89.

${ }^{50} \mathrm{Id}$.

${ }^{51} 1987$ Protocol Amending the 1978 Agreement, as Amended.
} 


\begin{tabular}{|c|c|c|}
\hline Annex 4 & $\begin{array}{l}\text { Discharges of Oil and Hazardous } \\
\text { Polluting Substances from Vessels }\end{array}$ & $\begin{array}{l}\text { Promotes regulation for the prevention of } \\
\text { discharges of harmful quantities of oil and } \\
\text { hazardous polluting substances from vessels. } \\
\text { Primarily aimed at preventing spills from tanks and } \\
\text { cargo (oil and chemical substances). }\end{array}$ \\
\hline Annex 5 & Discharges of Vessel Wastes & $\begin{array}{l}\text { Promotes regulation for the prevention of } \\
\text { discharges of a wastes, garbage, and sewages from } \\
\text { vessels (human wastes and other organics). Sewage } \\
\text { from vessels must be adequately treated. }\end{array}$ \\
\hline Annex 6 & $\begin{array}{l}\text { Review of Pollution from Shipping } \\
\text { Sources }\end{array}$ & $\begin{array}{l}\text { Canadian and U.S. Coast Guards to cooperate on } \\
\text { regulation of shipping activities that might impair } \\
\text { water quality. }\end{array}$ \\
\hline Annex 7 & Dredging & $\begin{array}{l}\text { Establishes a subcommittee on dredging in the } \\
\text { Water Quality Board. Review and criteria for } \\
\text { pollution loading from contaminated sediments } \\
\text { from dredging. }\end{array}$ \\
\hline Annex 8 & $\begin{array}{l}\text { Discharges from Onshore and } \\
\text { Offshore Facilities }\end{array}$ & $\begin{array}{l}\text { Promotes regulation of oil and hazardous polluting } \\
\text { substances from facilities including motor vehicles, } \\
\text { rolling stock, and pipelines. }\end{array}$ \\
\hline Annex 9 & Joint Contingency Plan & $\begin{array}{l}\text { References the CANUSLAK Annex to the Canada- } \\
\text { U.S. Joint Marine Pollution Contingency Plan. } \\
\text { Establishes a plan for joint response to pollution } \\
\text { incidents in the Lakes. }\end{array}$ \\
\hline Annex 10 & Hazardous Polluting Substances & $\begin{array}{l}\text { Parties are to maintain lists of pollutants and } \\
\text { programs and measures to minimize or eliminate } \\
\text { the risk of their release. Appendices have lists of } \\
\text { hazardous and potentially hazardous substances for } \\
\text { control. }\end{array}$ \\
\hline Annex 11 & Surveillance and Monitoring & $\begin{array}{l}\text { Needed to assess compliance, achievement of } \\
\text { objectives, overall trends in water quality, and new } \\
\text { problems. Also calls for monitoring of Annex } 2 \\
\text { programs and ecosystem health indicators (lake } \\
\text { trout and crustacean Pontoporeia hoyi). }\end{array}$ \\
\hline Annex 12 & Persistent Toxic Substances & $\begin{array}{l}\text { Regulatory strategies for controlling or preventing } \\
\text { input of toxics with half-life of greater than eight } \\
\text { weeks in water. Also calls for early warning system } \\
\text { for future toxic contaminations. }\end{array}$ \\
\hline Annex 13 & Pollution from Non-Point Sources & $\begin{array}{l}\text { Abatement and reduction of pollution from land-use } \\
\text { activities. Includes phosphorous, sediment, toxics, } \\
\text { and microbiologicals. Special reference to wetlands } \\
\text { preservation. }\end{array}$ \\
\hline
\end{tabular}




\begin{tabular}{|l|l|l|}
\hline Annex 14 & Contaminated Sediment & $\begin{array}{l}\text { Parties to identify and evaluate areas of } \\
\text { contaminated sediment. Also evaluations of } \\
\text { measures to remove, cap, or otherwise manage } \\
\text { sediment. }\end{array}$ \\
\hline Annex 15 & Airborne Toxic Substances & $\begin{array}{l}\text { Calls for research, surveillance and monitoring of } \\
\text { air deposition of toxics, particularly persistent toxic } \\
\text { substances, into the Great Lakes. References } \\
\text { Integrated Atmospheric Deposition Network. }\end{array}$ \\
\hline Annex 16 & $\begin{array}{l}\text { Pollution from Contaminated } \\
\text { Groundwater }\end{array}$ & $\begin{array}{l}\text { Parties to coordinate programs to control } \\
\text { contaminated groundwater "affecting the boundary } \\
\text { waters of the Great Lakes System". Recognizes } \\
\text { hydro-ecological connections between ground and } \\
\text { surface waters. }\end{array}$ \\
\hline Annex 17 & Research and Development & $\begin{array}{l}\text { Parties to conduct research on various issues } \\
\text { including ecosystem modeling, toxicity, and } \\
\text { variations in lake levels. }\end{array}$ \\
\hline
\end{tabular}

\section{B. The 2012 Great Lakes Water Quality Agreement}

The most recent revision of the GLWQA is an amending protocol of September 7, 2012, that updates the 1987 version. ${ }^{52}$ This GLWQA was signed by Lisa Jackson, from the U.S. EPA, and Peter Kent, Canadian Minister of the Environment. Two documents from the IJC - the Commission's 2006 special report to the two federal governments with advice for their review of the GLWQA, and the fifteenth Biennial Report on Great Lakes Water Quality - helped to start the conversation about a new GLWQA that would address the most pressing and pertinent ecological issues now facing the Lakes. ${ }^{53}$ The new Protocol begins by stating that the Parties are "reaffirming their commitment to achieve the goals and objectives of the 1978 Agreement" and also "recognizing the need to update and strengthen the 1978 Agreement to address current impacts on the quality of the Waters of the Great Lakes, and anticipate and prevent emerging threats to the quality of the Waters of the Great Lakes”. ${ }^{54}$ The amended GLWQA maintains much of the original's goals and purposes for coordination and cooperation between the United States and Canada, but updates on issues like aquatic invasive species and the effects of climate change.

A portion of the Revised 1978 Agreement kept and expanded in the 2012 version is the dedication of the parties to the ecosystem approach in management. ${ }^{55}$ The ecosystem approach is defined in "Principles and Approaches" in the GLWQA as "taking management actions that integrate the

\footnotetext{
${ }^{52}$ Great Lakes Water Quality Agreement of 2012, Protocol Amending the Agreement Between Canada and the United States of America on Great Lakes Water Quality, 1978, As Amended on October 16, 1983 and on November 18, 1987, available at http://www.ijc.org/en /Great Lakes Water Quality.

[Hereinafter 2012 Great Lakes Water Quality Agreement].

${ }^{53}$ IJC, 15th Biennial Report on Great Lakes Water Quality, 2011.

${ }^{54} 2012$ GLWQA at Preamble.

${ }^{55}$ See, e.g., Appendix to the Protocol of the 2012 GLWQA.
} 
interacting components of air, land, water, and living organisms, including humans”. Additional principles along these same lines include the dedication of the Parties and the IJC to use the best available science, incorporate the precautionary principle in management decisions, and consider issues of sustainability. The Parties in the 2012 Agreement recognize that "that restoration and enhancement of the Waters of the Great Lakes cannot be achieved by addressing individual threats in isolation, but rather depend upon the application of an ecosystem approach to the management of water quality that addresses individually and cumulatively all sources of stress to the Great Lakes Basin Ecosystem”. ${ }^{66}$ This language is comparable, but goes even further than that of the 1978 Agreement, that "restoration and enhancement of the boundary waters cannot be achieved independently of other parts of the Great Lakes Basin Ecosystem". ${ }^{57}$ The new Agreement's Specific Objectives now include a set of Lake Ecosystem Objectives that are to be established for each Great Lake and its connecting river system as a whole. ${ }^{58}$

In accordance with the fifteenth Biennial Report, the ecosystem management approach was extended to specifically include nearshore areas, as well as to the cold deep waters of the central Lakes. ${ }^{59}$ As the Report states, "adaptive management... is particularly appropriate for the nearshore waters of the Great Lakes because the dynamic nature of the nearshore zone increases the uncertainty of achieving optimal results from applied management actions". ${ }^{60}$ Although "nearshore issues" did not become one of the new annexes, adapting existing regulatory measures specifically to the nearshore zone was a priority in writing the 2012 GLWQA. The Parties in the new Preamble recognize that "that nearshore areas must be restored and protected because they are the major source of drinking water for communities within the basin, are where most human commerce and recreation occurs, and are the critical ecological link between watersheds and the open waters of the Great Lakes”. ${ }^{1}$

The 2012 GLWQA has ten annexes to the main text, which discuss different specific issues of concern for the two countries. ${ }^{62}$ Some of these are specific environmental problems, like Annex 3 Chemicals of Mutual Concern (aimed at specific pollutants) and Annex 4 - Nutrients (addressing nutrient pollution and its effects). Others discuss specific procedures for addressing issues like Annex 1 - Areas of Concern (which describes the process for establishing Areas of Concern in impaired waters) and Annex 10 - Science (emphasizing the "coordination, integration, synthesis, and assessment of science activities”). Fig. 2, below, shows the new list of annexes as presented in the 2012 GLWQA. It should be noted that some of the annexes are similar to those of the longer list in the previous version, but have been simplified and collapsed into larger categories (for example, compare former Annexes 4, 5, and 6 from the previous GLWQA to the new Annex 5). Multiple pathways of pollution and environmental harm that were previously listed in separate annexes have now been combined and the annexes are generally organized by type of environmental harm. Of particular note is the addition of Annex 9 - Climate Change Impacts, demonstrating the increased awareness of the Parties and the IJC of the potential effects of global climate change on the Great Lakes system. Another major shift in the new set of annexes is the

\footnotetext{
${ }^{56} I d$.

${ }^{57} 1978$ GLWQA, as Amended.

${ }^{58} 2012$ GLWQA, Article 3 (b) (i).

${ }^{59}$ IJC, 15th Biennial Report on Great Lakes Water Quality.

${ }^{60} \mathrm{Id}$., at 15.

${ }^{61} 2012$ GLWQA, Preamble.

${ }^{62} 2012$ GLWQA.
} 
change in chemical pollutants in Annex 3 from a specific set of appended substances to a more openended pollutant risk analysis, including chemicals of emerging concern. ${ }^{63}$

Figure 2: List of Annexes of the 2012 Great Lakes Water Quality Agreement

\begin{tabular}{|l|l|l|l|}
\hline Annexes of the 2012 GLWQA & Purpose & Key Differences \\
\hline Annex 1 & Areas of Concern & $\begin{array}{l}\text { Restoration of imparied } \\
\text { beneficial uses in AOCs with } \\
\text { Remedial Action Plans. }\end{array}$ & $\begin{array}{l}\text { Used to be part of former } \\
\text { Annex 2 with LAMPs. }\end{array}$ \\
\hline Annex 2 & $\begin{array}{l}\text { Lakewide } \\
\text { Management }\end{array}$ & $\begin{array}{l}\text { Establishment of Lake } \\
\text { Ecosystem Objectives (LEOs) } \\
\text { to assess water quality and } \\
\text { ecosystem health for Lake as a } \\
\text { whole. Also calls for integrated } \\
\text { nearshore framework. } \\
\text { Lakewide Action and } \\
\text { Management Plans for each } \\
\text { Lake and associated rivers. }\end{array}$ & $\begin{array}{l}\text { Keeps and expands LAMPS, } \\
\text { similar language to former } \\
\text { expanded from former Annex } \\
\text { 1 Supplement. }\end{array}$ \\
\hline Annex 3 & Chemicals of & $\begin{array}{l}\text { Attainment of General and } \\
\text { Specific Objectives for water } \\
\text { quality by coordinated control } \\
\text { of chemicals of mutual concern. } \\
\text { References domestic water } \\
\text { quality programs by Parties. }\end{array}$ & $\begin{array}{l}\text { Language much broader than } \\
\text { former annex text. No longer } \\
\text { contains appended list of } \\
\text { substances. }\end{array}$ \\
\hline Annex 4 & Nutrients & $\begin{array}{l}\text { Manage phosphorus (and other } \\
\text { nutrients if warranted) } \\
\text { concentrations and loadings. } \\
\text { Reduction of nutrient loading to } \\
\text { prevent harmful algal blooms } \\
\text { causing hypoxia, nuisance, } \\
\text { toxins, eutrophic status. Parties } \\
\text { to monitor and consult on } \\
\text { efficacy. }\end{array}$ & $\begin{array}{l}\text { Supplement in former Annex } \\
\text { 3. Keeps phosphorous load } \\
\text { target lists, no longer has } \\
\text { allocations by country. }\end{array}$ \\
\hline
\end{tabular}

${ }^{63}$ IJC, 15th Biennial Report on Great Lakes Water Quality, 2011. 


\begin{tabular}{|c|c|c|c|}
\hline Annex 5 & $\begin{array}{l}\text { Discharges from } \\
\text { Vessels }\end{array}$ & $\begin{array}{l}\text { Preventing and controlling } \\
\text { vessel discharges, including oil } \\
\text { and hazardous polluting } \\
\text { substances, garbage, wastewater } \\
\text { and sewage, biofouling } \\
\text { (invasives and pathogens), and } \\
\text { ballast water. References } \\
\text { domestic agencies and } \\
\text { International Maritime } \\
\text { Organization's guidance. }\end{array}$ & $\begin{array}{l}\text { Contains language from } \\
\text { former Annexes } 4,5,6 . \text { New } \\
\text { language on biofouling and } \\
\text { ballast water recognizes } \\
\text { pathway for invasions. }\end{array}$ \\
\hline Annex 6 & $\begin{array}{l}\text { Aquatic Invasive } \\
\text { Species }\end{array}$ & $\begin{array}{l}\text { Binational strategy to prevent } \\
\text { introduction of AIS, control or } \\
\text { reduce spread of existing AIS, } \\
\text { attempts to eradicate where } \\
\text { feasible. Notes uncertain nature } \\
\text { of future invasions and need for } \\
\text { risk assessments and new } \\
\text { controls. }\end{array}$ & $\begin{array}{l}\text { This annex is new. Mentions } \\
\text { potential impact of climate } \\
\text { change on AIS vectors } \\
\text { (Subsection C (7)). }\end{array}$ \\
\hline Annex 7 & $\begin{array}{l}\text { Habitat and } \\
\text { Species }\end{array}$ & $\begin{array}{l}\text { Maintaining and protecting } \\
\text { native species and their habitat. } \\
\text { Calls for "baseline survey of } \\
\text { existing habitat" to measure } \\
\text { gains and losses. Notes LAMPs } \\
\text { as principal mechanism for } \\
\text { coordinating conservation } \\
\text { efforts. Also includes definition } \\
\text { of "ecosystem services". }\end{array}$ & $\begin{array}{l}\text { This annex is new. Links } \\
\text { native species and habitat to } \\
\text { ecosystem approach and } \\
\text { ecosystem services. }\end{array}$ \\
\hline Annex 8 & Groundwater & $\begin{array}{l}\text { Improvement of "groundwater } \\
\text { science" by Parties. Calls for } \\
\text { management, protection, and } \\
\text { remediation of groundwater } \\
\text { quality. }\end{array}$ & $\begin{array}{l}\text { Focus shift from former } \\
\text { Annex } 16 \text { - groundwater to be } \\
\text { managed for itself as well as } \\
\text { for potential effect on Lakes. }\end{array}$ \\
\hline Annex 9 & $\begin{array}{l}\text { Climate Change } \\
\text { Impacts }\end{array}$ & $\begin{array}{l}\text { Calls Parties to coordinate on } \\
\text { identifying, understanding, and } \\
\text { predicting climate change } \\
\text { impacts on water quality of } \\
\text { Lakes. Parties should coordinate } \\
\text { water quality actions with water } \\
\text { quantity actions taken by IJC as } \\
\text { climate change links both. }\end{array}$ & $\begin{array}{l}\text { This annex is new. Focus is } \\
\text { on ultimate effects of climate } \\
\text { change on Great Lakes, no } \\
\text { language about mitigation or } \\
\text { greenhouse gasses. }\end{array}$ \\
\hline
\end{tabular}




\begin{tabular}{|l|l|l|l|}
\hline Annex 10 & Science & $\begin{array}{l}\text { Parties to improve science } \\
\text { (modeling, observation, } \\
\text { research, etc.) and improve } \\
\text { coordination on scientific } \\
\text { development. Facilitation of } \\
\text { information sharing and } \\
\text { comprehensive knowledge. }\end{array}$ & $\begin{array}{l}\text { Similar to former Annex } 17 . \\
\text { Language on incorporation of } \\
\text { traditional knowledge is new. }\end{array}$ \\
& & \\
\hline
\end{tabular}

In devising the new 2012 GLWQA, participation by the public and concerned stakeholders was requested by the involved agencies. According to the U.S. EPA, both nations sought out and utilized stakeholder input during the negotiations of the new GLWQA, and the finished agreement contains further provisions for public participation and notification by the IJC. ${ }^{64}$ One of the provisions of the protocol that has been maintained and expanded in the new version states that "while the Parties are responsible for decision-making under this Agreement, the involvement and participation of State and Provincial Governments, Tribal Governments, First Nations, Métis, Municipal Governments, watershed management agencies, local public agencies, and the Public are essential to achieve the objectives of this Agreement”. ${ }^{65}$ A previous review of the GLWQA was performed in 1999 "entirely by staff of federal, provincial, and state governments. The environmental nongovernment organizations, justly distrustful of this closed approach, successfully lobbied senior administrations (such as administrators and deputy ministers) to terminate the review before any revisions were contemplated by the Parties. Learning from this error in process, the governments opened the review to public participation in 2006." ${ }^{66}$ However, the later negotiations of the 2012 Agreement were not viewed as having successfully integrated all of the Great Lakes environmental community. The Citizens Environment Alliance ${ }^{67}$ and a long list of environmental organizations ${ }^{68}$ have both expressed concerns about a lack of public participation in the Agreement and in the IJC.

${ }^{64}$ Valentine, Julia P., “United States and Canada Sign Amended Great Lakes Water Quality Agreement”, United States Environmental Protection Agency News Release, September 7, 2012, available at http://yosemite.epa.gov/opa/admpress.nsf/d0cf6618525a9efb85257359003fb69d/9e6415ec5260e5c88525 7a7200669766! OpenDocument

652012 GLWQA, Preamble.

${ }^{66}$ Krantzberg, supra FN 47.

${ }^{67}$ Citizens Environment Alliance of southwestern Ontario, CEA Concerned about Insufficient Public Participation in GLWQA Renegotiation Process, press release of February 18, 2010. (Expresses group's concern over lack of adequate time for comment on governance issues for the 2012 Agreement.) Available at http://www.citizensenvironmentalliance.org/pressreleases/GLWQA\%20renegotiation\%20media\%20relea se.pdf.

${ }^{68}$ Letter Re: IJC Great Lakes Water Quality Bard and other Boards: Comments on composition and structure, February 8, 2013. (Expresses concerns that IJC’s Water Quality Board may be too closely connected to governments and therefore unable to critique their actions, requests additional public involvement.) Available at http://www.citizensenvironmentalliance.org/pressreleases/Letter\%20to\%20IJC\%20re\%20WQB\%20Feb\% 208,\%202013\%20Signed-1.pdf. 


\section{Additional Applicable Transboundary Law}

Canada and the U.S. have also signed an Air Quality Agreement recognizing that transboundary air pollution is a serious problem and pledging to work together to reduce air pollution and deposition. The Air Quality Agreement follows in the cooperative vein of the GLWQA, emphasizing interconnected environmental degradation and protection. The Air Quality Agreement references the Stockholm Declaration of the United Nation's Principle 21, affirming a nation state's right to exploit their own resources with the caveat that such activities should not damage the environments of other states. ${ }^{69}$

The U.S. EPA and Environment Canada have also signed an agreement to reduce Great Lakes pollutants; the Canada-United States Strategy for the Virtual Elimination of Persistent Toxic Substances in the Great Lakes Basin. As the Strategy states, the purpose "is to set forth a collaborative process by which Environment Canada (EC) and the United States Environmental Protection Agency (USEPA), in consultation with other federal departments and agencies, Great Lakes states, the Province of Ontario, Tribes, and First Nations, will work in cooperation with their public and private partners toward the goal of virtual elimination of persistent toxic substances resulting from human activity, particularly those which bioaccumulate, from the Great Lakes Basin, so as to protect and ensure the health and integrity of the Great Lakes ecosystem. ${ }^{70}$ The Binational Toxics Strategy is based on Article II of the 1987 GLWQA, which stated that "...the discharge of any and all persistent toxic substances be virtually eliminated" and Article VI that "measures for the control of inputs of persistent toxic substances including control programs for their production, use, distribution, and disposal” were needed on a consistent and cooperative basis. ${ }^{71}$ As the Strategy notes, "[s]ince that time, both countries have undertaken their own virtual elimination efforts, Canada through its Toxic Substances Management Policy (TSMP), and the U.S. through its Virtual Elimination Pilot Project”. ${ }^{72}$ The 2012 GLWQA has similar language, stating in Article II that the parties must "eliminate or reduce, to the maximum extent practicable, environmental threats to the Waters of the Great Lakes" and embracing among its Principles the "polluter pays" principle (in line with the Rio Declaration on Environment and Development), “virtual elimination”, and "zero discharge, again "where appropriate". ${ }^{73}$ The Annexes to the 2012 GLWQA, as stated above, no longer contain a list of hazardous substances, but have replaced it with the Annex on Chemicals of Emerging Concern. The Binational Toxics Strategy, on the other hand, maintains lists of chemicals found by one or both countries to be persistent hazardous pollutants.

Other domestic law and policies in the U.S. and Canada expand the coverage of Great Lakes issues. In the U.S. the Clean Water and Clean Air Acts are the main legislative bases for water and air quality regulation by the U.S. EPA and state regulatory agencies. Other agencies, like the U.S. Fish and Wildlife Service also work with states and other agencies on environmental regulation. In Canada the Canadian Environmental Protection Act is the major statute underlying environmental regulation.

\footnotetext{
${ }^{69}$ Agreement between the Government of Canada and the Government of the United States on Air Quality, Preamble, 1991. Available at http://www.ijc.org/en /Air_Quality Agreement; see also http://www.epa.gov/airmarkets/progsregs/usca/index.htm.

${ }^{70}$ Canada-United States Strategy for the Virtual Elimination of Persistent Toxic Substances in the Great Lakes Basin, April 7, 1997, available at http://binational.net/bns/strategy_en.pdf.

${ }^{71}$ Id. at 2.

${ }^{72} \mathrm{Id}$.

${ }^{73} 2012$ GLWQA, Article II.
} 
Environment Canada and the provincial governments also cooperate amongst themselves and with stakeholders to protect the environment.

The Great Lakes Charter of $1985^{74}$ was created by the Council of Great Lakes Governors to add additional management goals and principles for the regulation of water resources of the Lakes. The Charter's purposes include: conservation of the levels and flows of the Great Lakes and their connecting waters, protection of the environmental balance of the basin ecosystem, cooperative management between signatory States and Provinces, and protecting development and investment. ${ }^{75}$ The Charter encourages the signatories to work together cooperatively to manage their shared water resources while considering the concerns of other jurisdictions and the actions of the IJC. ${ }^{76}$

In addition the Council of Governors in 2005 signed the Great Lakes-St. Lawrence River Basin Water Resources Compact and its companion the Great Lakes-St. Lawrence River Basin Sustainable Water Resources Agreement. ${ }^{77}$ The Compact and Agreement address water quantity issues by limiting diversions outside of the basin of the Great Lakes and pledge the signatory States and Provinces to maintain the water resources of the Lakes for multiple in-basin uses. ${ }^{78}$ The Agreements "put riparian water use rules and environmental protection standards into a proactive public law regime in eight states and two Canadian provinces.”79

This discussion does not even come close to representing the full slate of agreements, policies, strategies and laws that intersect in the management of the Great Lakes. Instead, it demonstrates the complex overlapping layers of jurisdictions at play in the system.

\footnotetext{
${ }^{74}$ Great Lakes Governors' Task Force, The Great Lakes Charter, Principles for the Management of Great Lakes Water Resources, 1985 Final Report and Recommendations: Great Lakes Governors’ Task Force on Water Diversions.

${ }^{75}$ Saunders, Law and the Management of the Great Lakes Basin, supra FN 3. ${ }^{76} \mathrm{Id}$.

${ }^{77}$ Great Lakes-St. Lawrence River Basin Water Resources Compact, Dec. 13, 2005. Available at http://www.cglg.org/projects/water/docs/12-13-05/Great_LakesSt Lawrence River Basin Water Resources Compact.pdf. Great Lakes-St. Lawrence River Basin Sustainable Water Resources Agreement, Dec. 8, 2008. Available at http://www.cglg.org/projects/water/docs/12-13-05/Great LakesSt Lawrence River Basin Sustainable Water Resources Agreement.pdf.

${ }^{78}$ See discussion of Agreements at The Council of Great Lakes Governor's website at http://www.cglg.org/projects/water/Agreement-Compact.asp.

${ }^{79}$ Noah D. Hall, Toward a New Horizontal Federalism: Interstate Water Management in the Great Lakes Region, University of Colorado Law Review, 77, 2006. Available at http://www.greatlakeslaw.org/blog/files/Hall_Colorado.pdf.
} 


\section{SECTION 2: ENVIRONMENTAL ISSUES}

This Section discusses major ecological issues affecting the Great Lakes ecosystems and hydrology. The major categories of environmental harms are: pollutants, habitat loss, and invasive species. Reports, articles, and books abound on each of these environmental stressors, and the following discussions are more illustrative than exhaustive. It should be noted that these issues are widespread but variable; extremely complex and often interrelated. Therefore, the following should be understood as a means of methodically dividing the issues into categories to be addressed in turn, rather than an advocacy statement that these issues are somehow distinct and should be separated artificially. Nearly every piece of scientific writing on Great Lakes environmental problems has had to come up with a categorization scheme along these lines, including the annexes to the GLWQA.

\section{A. Pollution}

\section{i. Toxic Pollutants}

Toxic pollutants are defined as materials contaminating the environment that cause death, disease, birth defects in organisms that ingest or absorb them. The quantities and length of exposure necessary to cause these effects can vary widely and is often subject to controversy. ${ }^{80}$ There have been a number of different control programs addressing many different toxic pollutants as the GLWQA has developed. These toxics - including heavy metals, PCBs, DDT and dioxin, and now chemicals of emerging concern like synthetic hormones - have come from many different sources, rendering attempts to control them even more difficult. The IJC estimates that tens of thousands of industrial substances are in use in the United States and Canada, and relatively few of them have been evaluated for harm to human health or the environment, let alone regulated. ${ }^{81}$

One of the earliest sources of toxic pollution was the initial mining boom around the Great Lakes, beginning in approximately the 1840s. ${ }^{82}$ Iron and copper mining left acids and metal-laced leachate that ended up in the Lakes, steel manufacturing used multiple toxic chemicals and required tremendous use of water for temperature control. There are numerous examples of major polluting events in the early industrial boom around the Lakes, including a slag dump in Minnesota that left a large piece of the lakebed of Superior covered in "a carpet of carcinogenic asbestos fibers". ${ }^{83}$

Heavy metals of concern in the Lakes include lead, mercury, cadmium, zinc, and their related chemical compounds. ${ }^{84}$ These metals, particularly mercury and lead, have been the focus of regulatory action, and concentrations have declined since the mid-1970s. The Michigan Department of Environmental Quality report in 2000 attributes the reduction in overall concentrations to use of

\footnotetext{
${ }^{80}$ EPA, Drinking Water Glossary: A Dictionary of Technical and Legal Terms Related to Drinking Water, Last updated February 17, 2009.

${ }^{81}$ 15th Biennial Report, at 37.

${ }^{82}$ Ashworth, supra FN 43 at 88.

${ }^{83} \mathrm{Id}$. at 89.

${ }^{84}$ Great Lakes Trends: Into the New Millennium, Michigan Office of the Great Lakes, Michigan Department of Environmental Quality, May 2000.
} 
alternative materials, improved production methods with less pollution release, and better recovery and treatment, and believes that the reporting of chemical releases under the Toxic Release Inventory has pushed industrial polluters to make these improvements. ${ }^{85}$ Some metal contaminants, however, like mercury have not decreased but rather shifted sources. Although overall use of mercury in the United States has decreased, mercury now pollutes the Lakes from the atmosphere, released by municipal waste incinerators and burning coal. ${ }^{86}$

Industrial production and domestic use of other toxic chemicals have caused additional ecological degradation. Pesticides, cleaning chemicals, and industrial by-products have all been ending up in the Lakes and causing great concern. By the time the 1972 GLWQA was signed fifty eight million pounds of toxic chemicals were being discharged into the Great Lakes every year. ${ }^{87}$ The pesticide Mirex, for example, was found to be so dangerous that the 1978 GLWQA set the total allowable load of this chemical as "less than detection levels"; if you could tell it was there at all you were in trouble. ${ }^{88}$ It is still on the list of "substances to be virtually eliminated" under the Great Lakes Binational Toxics Strategy. ${ }^{89}$

A substantial list of these persistent toxics (including insecticides, mercury compounds, and PCBs) was gathered for the Binational Toxics Strategy from EPA, Environment Canada, and other Great Lakes reports. ${ }^{90}$ Substances listed for Virtual Elimination were split into two categories; Level I chemicals that both countries had proof were dangerous, and Appendix 2 chemicals that one or the other of the countries believed was or could be dangerous. These toxics are:

Level I:

Aldrin/dieldrin

Benzo(a)pyrene $\{\mathrm{B}(\mathrm{a}) \mathrm{P}\}$

Chlordane

DDT (+DDD+DDE)

Hexachlorobenzene (HCB)

Alkyl-lead

Mercury and mercury compounds

Mirex

Octachlorostyrene

PCBs

PCDD (Dioxins) and PCDF (Furans)

Toxaphene

Level II:

Cadmium and cadmium compounds

1,4-dichlorobenzene

3,3'-dichlorobenzidine

Dinitropyrene

${ }^{85} \mathrm{Id}$.

${ }^{86} \mathrm{Id}$. at 14 .

${ }^{87}$ Wayne Grady, The Great Lakes: The Natural History of a Changing Region, Greystone Books; First Trade Paper Edition, e-pub edition, 2011.

${ }^{88}$ Ashworth at 162.

${ }^{89}$ Great Lakes Trends: Into the New Millennium.

${ }^{90}$ Canada-United States Strategy for the Virtual Elimination of Persistent Toxic Substances in the Great Lakes Basin, April 7, 1997, Appendix I, available at http://binational.net/bns/strategy_en.pdf. 
Endrin

Heptachlor (+Heptachlor epoxide)

Hexachlorobutadiene (+Hexachloro-1,3-butadiene)

Hexachlorocyclohexane

4,4'-methylenebis(2-chloroaniline)

Pentachlorobenzene

Pentachlorophenol

Tetrachlorobenzene (1,2,3,4- and 1,2,4,5-)

Tributyl tin

Plus PAHs as a group, including but not limited to:

Anthracene

Benzo(a)anthracene

Benzo(g,h,i)perylene

Perylene

Phenanthrene

Progress has been made on reducing concentrations of some of these toxic pollutants in some of the Great Lakes. The Michigan DEQ 2000 Report, for example, points out that populations of Bald Eagles, once significantly impaired by bioaccumulations of substances like DDT and PCBs, have rebounded since the advent of strict regulations on pesticides and PCBs. However Great Lakes fish consumption advisories for dioxin, PCBs, methyl mercury, toxaphene, chlordane, and DDT are still issued. ${ }^{91}$

Some of these pollutants are coming from new pathways. Air deposition of multiple toxics - lead and mercury, PCBs - into the water was not so easy to regulate. ${ }^{92}$ In contrast to the outlet pipes of an industrial smelter, air deposition is a much more difficult pathway to identify and control. The same is true of regulation of other non-point sources, like urban storm water runoff. Additionally, sediments are holding a great deal of these toxics at the bottom of the Lakes, at levels that would be dangerous even if all chemical loading stopped tomorrow. ${ }^{93}$ PCBs are released from sediments stirred up by everything from canal dredging to benthic creatures digging for plankton. "Legacy contaminants” are pollutants largely left over from past practices that continue to recirculate through the ecosystem. ${ }^{94}$

Besides the usual suspects of heavy metals and PCBs, chemicals with new mechanisms of biologic harms are being identified. Chemicals of emerging concern (CECs), discussed in Annex 3 of the 2012 GLWQA are unregulated or inadequately regulated chemicals that may place human health and ecosystem function at risk. ${ }^{95}$ The 15th Biennial Report of the IJC has identified the following as CECs detected in the Great Lakes in 2011:

Synthetic musks

Fluorinated surfactants

Brominated diphenyl esters

${ }^{91}$ 15th Biennial Report.

${ }^{92}$ Grady.

${ }^{93}$ Great Lakes Trends: Into the New Millennium.

${ }^{94}$ GLRI Action Plan

95 15th Biennial Report. 
Other flame retardants

Alkylphenol ethoxylates

Chlorinated paraffins

Phthalates

Pharmaceuticals, veterinary drugs, and personal care products

Current use pesticides

Pathways by which these new chemical threats reach the Lakes include wastewater treatment plant discharges, sewage overflows, agricultural runoff, landfill leachate, and long-range atmospheric deposition. ${ }^{96}$ Unfortunately, some of the mechanisms of harm of these CECs are not fully understood. The function of synthetic hormones in drinking water from pharmaceuticals, for example, has the potential to disrupt the endocrine systems of animals and humans, particularly at early stages of development. These endocrine disrupting chemicals are still being studied in the U.S. by the EPA, but they remain unsure how to regulate them. ${ }^{97}$ Annex 3 of the 2012 GLWQA recommends preparing binational strategies for further action with "research, monitoring, surveillance, and pollution prevention and control provisions". ${ }^{98}$ Also mentioned is research and monitoring for the early identification of chemicals that could become CECs in the future. ${ }^{99}$

Another reason that the elimination of toxics has been less than wholly successful in the Great Lakes is that these chemicals interact in complex ways with other ecological processes. For example, mercury in the sediments of a lake with low oxygen (a lake experiencing eutrophication) is converted by anaerobic bacteria into methyl mercury which is highly bioaccumulative. ${ }^{100}$ This combination of eutrophication and toxic pollution poisons fish, and birds, and ultimately humans at the top of the food chain. Another ecological problem, the loss of wetlands along the Great Lakes, has also exacerbated the problem of toxics. Wetlands act as natural filters for surface water, they are "the kidneys and liver" of the Lakes. ${ }^{101}$ With the loss of wetlands comes a higher level of water and sediment pollutants.

\section{ii. Disease Pollutants}

One of the earliest pollution concerns in the Great Lakes was the spread of diseases from untreated sewage released into the same water system where major new cities like Chicago were also getting their drinking water. In 1900 the Chicago wastewater project reversed the flow of the Chicago River out of Lake Michigan to flush its sewage away; for a given definition of "away" that was really "downstream into the water of the citizens of Missouri" and ultimately into the Mississippi River. The state of Missouri sued the state of Illinois, alleging that this reversed river was causing outbreaks of typhoid and other Great Lakes states around Lake Michigan joined in to express their concerns over loss

\footnotetext{
${ }^{96} \mathrm{Id}$.

${ }^{97}$ See, e.g., Debra Goldberg, What you don't know about chemicals can hurt you: EPA's proposed policy statement for the endocrine disruptor screening program, 6 Envtl. Law. 209, 1999.

${ }^{98} 2012$ GLWQA, Annex 3.

${ }^{99} \mathrm{Id}$.

${ }^{100}$ Grady.

${ }^{101}$ Grady.
} 
of water from the Lake. ${ }^{102}$ Ultimately the contagion could not be proven - in part because there were so many sources of bacteria in the water that any one state or city could not be held exclusively responsible and the U.S. Supreme Court dismissed the case, but the dumping of wastewater from many different cities and towns continued. "During the 1940s and 1950s, many beaches around [Lake Erie] had to be closed as health hazards; the city of Cleveland was forced to move the main intake for its water system from half a mile offshore to five miles out [due to] "dangerously high counts of fecal coliform bacteria.”...The Lake's shore waters were, in many places, well on their way to becoming the functional equivalent of a septic tank.” ${ }^{\prime 103}$ The cities of Buffalo and Detroit were dumping almost entirely untreated sewage into their eponymous rivers, along with industrial effluent full of toxic chemicals, oils and paints, and just plain garbage. ${ }^{104}$ Seriously acrimonious Public Health Service hearings took place in 1965, with cities and states blaming each other for the high levels of pollution and the threat of disease. ${ }^{105}$ Then, in 1969 , the massively polluted Cuyahoga River caught fire, bringing "negative national publicity to Cleveland and its polluted waterways". ${ }^{106}$

Pathogens, and in particular fecal coliform bacteria, continue to be a major pollution problem and health hazard around the Lakes. Recreational beaches on Lake Huron, Lake Michigan, Lake St. Clair and multiple other areas of the Great Lakes are periodically closed by local health departments due to high levels of E. coli bacteria. ${ }^{107}$ Escherichia coli bacteria live in the intestines of humans and other animals, and are transmitted in fecal matter. ${ }^{108}$ They can cause a range of disease symptoms, from uncomfortable diarrhea to dangerous toxicity. ${ }^{109}$ The Great Lakes Information Network notes that "Great Lakes states and provinces all adhere to similar but slightly different bacterial water quality standards. Nevertheless, all bacterial water quality standards are based on estimates that ensure a low risk of illness in people.”110 Viral pathogens breathed in from the surface of the water, ingested, or contacted with skin while swimming or playing on a beach can also cause respiratory, gastrointestinal, ear and skin infections in humans. ${ }^{111}$ New disease pollutants include diseases that are themselves invasive species recently transferred to the Great Lakes region; for example the North American strain of viral hemorrhagic septicemia found in Lake St. Clair in 2003. ${ }^{112}$

Sources of bacterial pollutants today have shifted from untreated municipal sewage to more nonpoint sources, like urban runoff, livestock and pet wastes, and faulty septic systems. ${ }^{113}$ Animal species, especially birds, which live on the beaches and nearshore waters of the Great Lakes also pass along disease pollutants. Agricultural sources have also outstripped human sources in loading bacteria into the

\footnotetext{
${ }^{102}$ Missouri v. Illinois, 200 U.S. 496, 1906 U.S. LEXIS 1494.

${ }^{103}$ Ashworth at 123.

${ }^{104}$ Id. at 133.

${ }^{105}$ Id. at $140-141$.

${ }^{106}$ Michael Rotman, “Lake Erie” Cleveland Historical, accessed March 2, 2013, available at http://clevelandhistorical.org/items/show/58.

${ }^{107}$ EPA, Beach Survey Results on the Web, Issue 58, 1999.

${ }^{108}$ Great Lakes Information Network, Beach Health and Water Quallity, Beachcast, available at http://www.great-lakes.net/beachcast/faq.html.

${ }^{109} \mathrm{Id}$.

${ }^{110} \mathrm{Id}$.

111 15th Biennial Report, IJC, at 29.

${ }^{112}$ GLRI Action Plan, at 23.

${ }^{113}$ 15th Biennial Report.
} 
Lakes, according to a study in Lake Huron. ${ }^{114}$ Discharges of wastewater from vessels into the Lakes are also addressed in Annex 5 of the 2012 GLWQA.

An additional complicating interaction in the ongoing presence of such bacteria is their connection to eutrophication and algal blooms. Mats of Claodophora algae provide shelter and nutrients for enteric bacteria, including human pathogens (e.g. E. coli, enterococci, Campylobacter, Salmonella) that later detach from the algal mats and are moved by waves and wind into the water and onto the beaches. ${ }^{115}$ Traditional beach monitoring can fail to detect these additional repositories of bacteria, and thus underestimate the danger to the public during summer algal blooms. ${ }^{116}$

Beaches and recreational water quality continue to be a major issue for the Great Lakes, and are discussed at length in the 15th Biennial Report from the IJC. Tourism and recreation are extremely important for the economy of the Great Lakes. The Report notes that there were 3,000 days of beach closings and advisories in 2005, and that a reduction in closings of twenty percent would result in a \$130 to $\$ 190$ million benefit to the regional economy. ${ }^{117}$ However, inconsistent standards between beaches in different jurisdictions have also caused problems for the public in determining when it is truly safe to use public beaches. ${ }^{118}$ The report calls for improved coordination between the nations, states, and local authorities in setting up more effective and consistent monitoring and posting standards to protect the public health and promote the use of Great Lakes beaches. ${ }^{119}$ Besides the harm to the Great Lakes economy from the loss of recreational opportunities lurks the continuing danger of serious health crises from disease pollutants in the water. An outbreak of E. coli in May of 2000 in Walkerton, Ontario, in an untreated water system after an exceptionally heavy rainfall sickened thousands and killed seven citizens. ${ }^{120}$

\section{iii. Nutrient Loading}

Nutrient pollution, primarily phosphorous and nitrogen loading and associated algal blooms, have been one of the most visible environmental issues in the Great Lakes. The problem has had to be addressed and re-addressed in multiple versions of the GLWQA as the complexity of the issue has evolved.

Lakes need minimum levels of nutrients in order to have biologic growth take place. The element, mechanism, or factor that is in shortest supply limits the total amount of growth possible. In the Great Lakes system, it is often the total amount of dissolved reactive phosphorous (DRP) that limits the growth of the algae which form the basis of the Lake's food web. Dissolved inorganic nitrogen (principally ammonium and NOx) is the other major basis for this system and the other major nutrient pollutant in the

\footnotetext{
${ }^{114} \mathrm{Id}$.

${ }^{115}$ M. P. Verhougstraete, M. N. Byappanahalli, J. B. Rose and R. L. Whitman, Cladophora in the Great Lakes: impacts on beach water quality and human health, Water Science \& Technology 62.1, 2010.

${ }^{116} I d$.

${ }^{117}$ 15th Biennial Report, IJC, at 28.

${ }^{118} I d$.

${ }^{119} I d$.

${ }^{120}$ Botts and Muldoon, at 146.
} 
Great Lakes system. ${ }^{121}$ With appropriate levels of nutrients algae in the lakes can photosynthesize, grow, and spread. When the levels are too low, little growth takes place and the lake is known as oligotrophic. When the inorganic nutrients are increased, the system becomes more productive in a process known as eutrophication. Multiple factors beyond the amount of nutrients affect a lake's trophic state, including its depth and the amount of movement in the water. ${ }^{122}$ Large blooms of algae, or prodigious growth of submersed macrophytes, can cause several different kinds of problems in eutrophic lakes: some bluegreen algae (cyanobacteria) are toxic; other species like Cladophora form large masses of living, dying and dead algae that impair water quality and uses of the lake in and of themselves, and also cause hypoxia. Dense growths of aquatic weeds have the same effect. The decomposition of this biomass can cause an oxygen deficit (hypoxia) when they decompose that is harmful to other species, particularly benthic invertebrates and fishes. ${ }^{123}$

Lake Erie is particularly prone to phosphorous overloads, and was borderline eutrophic even before anthropogenic nutrients were added to its watershed. As Wayne Grady writes in his history The Great Lakes: "Lake Erie is rich in nutrients thanks to the fertile, easily eroded soils that surround it and the roughly 86 centimeters (34 inches) of precipitation that falls annually in its drainage basin, washing soil and minerals into the lake in the spring and after each rainfall”. ${ }^{124}$ In addition, large amounts of pollution, including high levels of nitrogen and phosphorus, lead to extreme eutrophication events in the 1960s, sparking the popular phrase "Lake Erie is dead!" to appear in the national media. ${ }^{125}$ Phosphorous reduction activities from point source pollution control reduced the eutrophication of Lake Erie after these events, but bioavailable phosphorous persisted in the system and the algae growths returned in the late 1990s. ${ }^{126}$ Lake Erie is still one of the Great Lakes most particularly subject to eutrophication, due in large part to its shallow basin and its high level of drainage from the surrounding watersheds. ${ }^{127}$ The summer of 2010, for example, saw major water quality problems in Lake Erie from both eutrophication-based hypoxia and harmful algal blooms (HABs) of toxic cyanobacteria. ${ }^{128}$

Lake Superior, by contrast, was much slower in showing the effects of nutrient loading. Unlike Lake Erie, Superior is deep and cold, and tends towards oligotrophy. With forty percent of its drainage basin occupied by the surface of the Lake itself, there is less opportunity for nutrients and minerals to be added by precipitation run-off from the surrounding land. ${ }^{129}$ Lake Erie only occupies around twenty-eight percent of its drainage basin. Ashworth writes of Superior in the 1960s, as the furor over Lake Erie grew,

${ }^{121}$ See, e.g., E. B. Welch and J. M. Jacoby, Pollutant Effects in Freshwater: Applied Limnology, 3d Ed. 2004. (This book provides an excellent, if somewhat technical explanation of the complex and interrelated mechanisms of nutrient pollution and eutrophication.)

${ }^{122} I d$. at 186.

${ }^{123}$ Id. at 200.

${ }^{124}$ Grady, at 31.

${ }^{125}$ Michael Rotman, Cleveland Historical, "Lake Erie”, available at http://clevelandhistorical.org/items/show/58, (last accessed 2/3/13).

${ }^{126}$ Ohio Lake Erie Phosphorous Task Force Final Report, Ohio EPA, April 2010.

${ }^{127}$ Ohio EPA, Ohio DNR, and Ohio D of Ag., Nutrient Reduction Strategy Framework for Ohio Waters, Draft for US EPA Region 5 Review, Nov. 5, 2011. Available at http://epa.ohio.gov/portals/35/documents/nutrient_reduction_strategy_framework.pdf, last accessed 2/3/13.

${ }^{128} I d$. at "Recent Trends" pp. 4.

${ }^{129}$ Grady, at 249. 
"[t]here was no eutrophication in Superior; and given its depth, its potion at the top of the great chain of freshwater oceans, and the rock-bound, nearly sterile quality of its watershed, the limnologists who had studied it didn't think there ever could be. Thus was born the myth of Superior's invulnerability”. ${ }^{130}$ Ultimately, however, all of the Great Lakes began to show signs of nutrient pollution. Nearshore areas and restricted bays like Saginaw Bay in Lake Huron and Green Bay in Lake Michigan were both notable for extreme eutrophication and algal bloom events - in fact, as environmental historian William Ashworth points out, "Green Bay” is green because of the water's color with a superabundance of algae present. ${ }^{131}$

Reducing eutrophication in the Great Lakes was one of the earliest priorities of the GLWQA, and in many ways was a notable success. ${ }^{132}$ Binational cooperation on identifying and limiting phosphorous loading, primarily from point sources, greatly reduced the total phosphorous in the watersheds of the Great Lakes. Wastewater, in particular, was an early target of GLWQA regulation and reduction. ${ }^{133}$ The U.S. Clean Water Act and the Canada Water Act both set regulatory limits on nutrient loading, particularly for waste water treatment plants. By 1975 Lake Erie was experiencing its first algal bloomfree summer in a decade. ${ }^{134}$

Unfortunately, the problem of nutrient pollutants was not fully solved by these point source regulations. Like the disease pollutants above, new sources of phosphorous and nitrogen have continued to drive algal blooms and related hypoxia in the Lakes. For example, although the amount of phosphorous entering Lake Erie in 2000 had decreased by approximately ten thousand metric tons a year since 1972, the phosphorous levels in the waters of the central and eastern basins of the Lake continued to rise. ${ }^{135}$ "In recent years, however, its [the most visible signs of eutrophication] - nuisance Cyanobacteria (blue-green algae) blooms and rotting shoreline piles of the green macro-algae Cladophora - have returned to all the Great Lakes except Superior." ${ }^{136}$ Nutrient pollution is the topic of Annex 4 of the 2012 GLWQA, and reiterates the need to reduce phosphorous loading and total phosphorous concentrations in open waters. The Annex still requires the parties to improve their regulation of point source loading from wastewater, but also considers loading from industrial discharges, agricultural and rural loading (both point and nonpoint source), and household loading of phosphorous in detergents. ${ }^{137}$ The 15th Biennial Report from the IJC also recommends redoing the Commission's Pollution from Land Use Activities Reference Group (PLUARG) study to improve understanding of the new pathways and mechanisms of eutrophication. ${ }^{138}$

The effect of this ongoing nutrient pollution, even at a reduced level, has been exacerbated by the effects of invasive species and climate change. ${ }^{139}$ Climate change has contributed to eutrophication with warmer water temperatures that spur more growth and more runoff from extreme precipitation and

\footnotetext{
${ }^{130}$ Ashworth, at 140.

${ }^{131}$ Id. at 138.

132 15th Biennial Report on GL Water Quality at 23.

133 Ashworth at 133.

${ }^{134} \mathrm{Id}$. at 145.

${ }^{135}$ Great Lakes Trends: Into the New Millennium, at 4.

136 15th Biennial Report at 22.

1372012 GLWQA, Annex 4(D).

138 15th Biennial Report at 25.

${ }^{139}$ U.S. EPA, "Status of Nutrients in the Lake Erie Basin, Lake Erie Nutrient Science Task Group for the Lake Erie Lakewide Management Plan”, 2009, cited in Ohio Nutrient Reduction Strategy Framework supra at FN 127.
} 
stormwater overflows. ${ }^{140}$ The presence of invasive zebra and quagga mussels are also contributing to the reoccurrence of eutrophication in the Lakes due to their retention and recycling of nutrients on the nearshore bottomlands. ${ }^{141}$

\section{B. Habitat Loss}

\section{i. Coastal Communities and Wetlands Loss}

Wetlands, river mouths, sand dunes and nearshore waters are critically important habitat in the Great Lakes. Loss of wetlands changes the biological and chemical interactions between land and water, with adverse effects like increased sedimentation, changes in river and stream flows, and the decline of fish and wildlife populations. ${ }^{142}$ Loss of coastal river-mouth wetlands reduces nutrient and sediment sequestration, increasing sediment and nutrient delivery to the nearshore Great Lakes. Rare wildlife live and reproduce in marshes, wetlands provide flood control and water filtration, coastal habitats provide refuges and spawning grounds for many species of Great Lakes fish. ${ }^{143}$ The Michigan Department of Environmental Quality estimates that half of the globally rare species in the Lake Michigan basin have coastal areas as primary habitat. ${ }^{144}$ "A narrow but ecologically important band of wetlands occurs along large stretches of the Great Lakes shoreline. These "fringing wetlands" are typically only 100 to 500 yards wide. They are concentrated along the large bays of the Great Lakes, and the largest remaining areas occur on Saginaw Bay, Green Bay and the St. Marys River. Smaller areas occur along all of the Great Lakes." 145 Beds of bulrushes in these marsh lands prevent erosion with their mats of strong roots, and provide sheltering habitat for species like the yellow perch (Perca flavescens). ${ }^{146}$

Overall, the wetlands and shorelines that exist today are only a fraction of the natural nearshore buffer ecosystems that were present two centuries ago. ${ }^{147}$ Not only the quantity, but the quality of remaining wetlands has been significantly decreased. ${ }^{148}$ Wetlands have been degraded by numerous processes, including dredging, draining and filling to make solid land, diking, pollution, and water level fluctuation. ${ }^{149}$ Wetlands have been filled in and built up for shore-side use for agriculture, recreation, housing, and industry. ${ }^{150}$

Changes in lake levels have also affected wetlands and coastal areas. In general, due in part to their sheer size, Great Lakes water levels tend to be fairly stable, but with regular natural fluctuations on a

\footnotetext{
140 15th Biennial Report at 22.

${ }^{141}$ Id. at 25.

${ }^{142}$ Great Lakes Trends: Into the New Millennium

${ }^{143}$ GLRI Action Plan; Guy J. Kelnhofer, Jr., Preserving the Great Lakes, prepared for National Water Commission, 1972.

${ }^{144}$ Great Lakes Trends: Into the New Millennium.

${ }^{145}$ US EPA, Protecting Wetlands Along the Great Lakes Shoreline, available at http://www.epa.gov/greatlakes/ecopage/wetlands/Wetland.pdf.

${ }^{146} I d$.

${ }^{147}$ Great Lakes Trends: Into the New Millennium.

${ }^{148} I d$.

${ }^{149} \mathrm{Id}$.

${ }^{150} I d$.
} 
seasonal cycle ${ }^{151}$. Ontario and Erie typically experience only a three meter seasonal depth change each year; the much larger Superior averages only one meter change. ${ }^{152}$ However, the Great Lakes levels are closely tied to climatic conditions in the basin, meaning that extreme temperature and precipitation events can cause the normally stable levels to become extremely high or extremely low. ${ }^{153}$ As climate change impacts continue to intensify, changing precipitation patterns and raising summer temperatures (which increase evaporation) the Lakes may fluctuate even further. Some fluctuation in lake levels appears to be needed for healthy wetlands, but extreme flooding events or long dry spells can both cause damage to these fragile ecosystems. Regulation of the lake levels by humans for shipping or recreation has further harmed the seasonal cycles that allowed wetlands to replenish themselves. ${ }^{154}$

There has been a renewed focus on wetlands protection and restoration in the years leading up the renegotiation of the GLWQA. One good example is the multi-stakeholder collaborative restoration of Metzger Marsh, which may, according to the US EPA Report on the GLWQA, "serve as a model for coastal wetland restoration in other parts of the Great Lakes". ${ }^{155}$ Major features of this ecological restoration include: construction of water level/fish control structures, a diverse aquatic plant community, and restored habitat for a diversity of fish and wildlife species. ${ }^{156}$ The Metzger Marsh project is one of ten flagship projects of the North American Waterfowl Management Plan. ${ }^{157}$ The 15th Biennial Report from the IJC recommends that the Parties "place a high priority on the protection and restoration of wetlands and forestlands to enhance the quality and resiliency of the Great Lakes ecosystem". ${ }^{158}$ Although not stated explicitly in the 2012 GLWQA, wetlands restoration and protection probably fall under the heading of Annex 7 - Habitat and Species. Other wetlands are listed as Areas of Concern (Annex 1) or included in Lake Management Plans (Annex 2).

\section{ii. Cold Oligotrophic Habitat Loss}

The cold, oligotrophic waters of the interiors of the Lakes provide habitat for many of the larger fish species that humans of the region prey on. There were an estimated 150 species of fish in the Great Lakes before Europeans arrived, including species like chubs (genus Couesius) that live in the open waters of the Lakes, and lake sturgeon (Acipenser fulvescens). ${ }^{159}$ Atlantic salmon (Salmo salar), lake trout

${ }^{151}$ USGS Great Lakes Science Center, Lake Ontario Water Levels/Wetlands, available at http://www.glsc.usgs.gov/main.php?content=research_wetland_current_ontario\&title=Wetlands0\&menu =research_NCE_wetland.

${ }^{152} I d$.

${ }^{153} I d$.

${ }^{154}$ Donald A. Wilcox, Effects of Lake Ontario Water-Level Regulation on Wetlands, USGS Great Lakes Science Center, available at http://www.glsc.usgs.gov/main.php?content=research wetland current ontario\&title=Wetlands0\&menu =research_NCE_wetland.

${ }^{155}$ United States Environmental Protection Agency United States Great Lakes Program Report on the Great Lakes Water Quality Agreement, Great Lakes National Program Office, December 1997, available at http://www.epa.gov/grtlakes/glwqa/usreport/usreport.pdf.

${ }^{156} \mathrm{Id}$.

${ }^{157}$ Id.

158 15th Biennial Report, at 20.

${ }^{159}$ Ashworth, at 115. 
(Salvelinus namaycush), and the lake whitefish (Coregonus clupeaformis) were all large predator species that were, in turn, eaten in large numbers by tribes and early European explorers and settlers. ${ }^{160}$

Several factors began decreasing the populations of these lake fish very quickly after 1900 . To begin with, they were massively overfished - lake whitefish numbers had declined below a level capable of sustaining commercial fisheries by $1910 .{ }^{161}$ Several invasive species (sea lampreys, domestic carp, and rainbow smelt) were also damaging the fish populations. Sea lampreys (Petromyzon marinus) are invasive parasitic predators (addressed in more detail in the next subsection). Smelt (Osmerus mordax) and carp (Cyprinus carpio) began occupying the habitat niches formerly held by Atlantic salmon and sturgeon. ${ }^{162}$ On top of these pressures, loss of wetlands and spawning streams, along with complex interactions of multiple pollutants, completed the decline of these fish populations. As the Great Lakes Fishery Commission notes on fish management: "[t]hese stresses have been so profound that they have challenged and broadened the thinking of fishery experts. Successful fish management of the Great Lakes is now actively focused on the lakes as ecosystems... Fishery management decisions must consider the potential effects on the whole system rather than only the effects within jurisdictional boundaries." 163 The management of these species and their habitat is extremely complex. "Stresses affecting fishery resources rarely act singly, often have complex interactions, and often impact several levels of the aquatic ecosystem so that remedial efforts must address problems on a comprehensive, whole-system basis.”164 Many species of native fish are now extinct in some or all of the Great Lakes. ${ }^{165}$ Unfortunately for the many stakeholders invested in the output of these fisheries, even more complications are starting to alter the habitat.

New ecological issues have the potential to disrupt the cold oligotrophic regions of the Lakes even further. Climate change is causing disruptions in the temperatures of the Lakes, and inhibiting their usual seasonal cycles. Fish are extremely sensitive to temperature, and therefore are particularly vulnerable to the effects of climate change. ${ }^{166}$ Not only do the warming temperatures themselves cause problems for species with low temperature tolerances, ${ }^{167}$ but the thermocline and thermal bar (bands of water of differing temperatures that generally prevent mixing except in certain seasons) could be disrupted by these increasing temperatures. ${ }^{168}$ In addition, new invasive species threaten to move into the Lakes, aided by a wider tolerance for warmer waters. Research projects like the Deep Water Science Project are continuing to study the cold oligotrophic habitat and its inhabitants to try to predict what the future will bring among these ongoing stressors. ${ }^{169}$ These factors, along with ongoing stresses from over-

\footnotetext{
${ }^{160} \mathrm{Id}$.

${ }^{161} I d$.

${ }^{162} I d$.

${ }^{163}$ Great Lakes Fishery Commission, Fish Management, available at http://www.glfc.org/fishmgmt/.

${ }^{164}$ Great Lakes Fishery Commission, Joint Strategic Plan for the Management of Great Lakes Fisheries, as revised 10 June, 1997, available at http://www.glfc.org/fishmgmt/jsp97.pdf.

${ }^{165}$ Great Lakes Fishery Commission, Healthy Great Lakes Ecosystems Vision Statement, available at http://www.glfc.org/pubs/vishea.htm.

${ }^{166}$ Welch and Jacoby, at 375.

${ }^{167}$ Great Lakes Trends: Into the New Millennium.

${ }^{168}$ Welch and Jacoby, at 29.

${ }^{169}$ See Report on the USGS Deep Water Science Project, Great Lakes Science Center, available at http://www.glsc.usgs.gov/main.php?content=research_DWS\&title=Deep\%20Water\%20Science0\&menu= research.
} 
harvesting, pollution, and loss of related habitats will make protecting the species of the interior Lakes even more difficult.

\section{iii. Benthic Habitat Loss}

Dredging, diking, filling and building in the nearshore areas of the Great Lakes has also done significant damage to benthic habitat and bottomlands. "The term benthic refers to anything associated with or occurring on the bottom of a body of water... Benthic habitats can best be defined as bottom environments with distinct physical, geochemical, and biological characteristics. Benthic habitats vary widely depending on their location and depth..." ${ }^{170}$ According to the Delaware Department of Natural Resources and Environmental Control, benthic habitat:

has three-dimensional structures that serve as shelter and provide storm protection by buffering wave action along coastlines; provides a complex environment for smaller creatures to hide in and/or attach to - and these areas may serve as valuable feeding areas for many larger species; is essential in maintaining water quality and provides a good indicator of health in estuarine ecosystems; plays a critical role in the breakdown of organic matter through the actions of scavengers, deposit-feeders, and bacteria; serves as important food sources for many species of fish, shellfish, and birds.

These important functions are also served by benthos (benthic species) in the bottomlands ${ }^{171}$ of freshwater lakes. The benthic habitat can also be thought of as the equivalent of the bottomlands portion of the “nearshore waters” described for particular protection in the IJC's 15th Biennial Report. Benthic species in the Great Lakes include arthropods, isopods, snails, and bivalve mollusks. ${ }^{172}$

Major ecological problems in the benthic habitat zone include the accumulation of toxic, nutrient, and disease pollutants in the sediment, which are then bioaccumulated and kicked up back into the water by scavengers or bottom feeders. Benthic zones have also been occupied by many aggressive invasive species (as discussed in the following subsection). Sedimentation, as in the wetlands, has also caused significant problems in already distressed benthic habitats. ${ }^{173}$ Eutrophication in the larger lakes primarily occurs in the shallower, warmer, more nutrient-rich waters above the benthic nearshore habitat, and hypoxia due to the decomposition of algal blooms is a serious problem for the benthos. ${ }^{174}$ The loss of benthic invertebrates like mayfly larvae was one of the first clues scientists had to the serious

\footnotetext{
${ }^{170}$ Dynamic Benthic Habitat, Delaware Coastal Programs, Division of Soil and Water Conservation, Department of Natural Resources and Environmental Control.

${ }^{171}$ To clarify - the term "bottomlands" is used here in the legal sense of land that lies below a body of water, rather than in the more ecological sense of lowlands or riparian zones near a river or other water body.

${ }^{172}$ See, e.g., The Great Lakes Environmental Research Laboratory’s Great Lakes Water Life Photo Gallery: Benthos of the Great Lakes, available at http://www.glerl.noaa.gov/seagrant/GLWL/Benthos/Benthos.html.

173 15th Biennial Report.

${ }^{174}$ Id.
} 
eutrophication problems in Lake Erie in the 1950s. ${ }^{175}$ The benthos species cannot survive in what has been described as an anoxic desert. ${ }^{176}$

Like wetlands and marshes, the benthic habitat is not discussed specifically in any detail in the 2012 GLWQA. Like the wetlands, benthic habitat is probably included under the general aegis of Annex 7 - Habitat and Species. Nearshore waters, including the bottomlands, are also probably included as Areas of Concern (Annex 1) or included in Lake Management Plans (Annex 2), as recommended by the IJC in the 15th Biennial Report.

\section{Invasive Species}

\section{i. Plant Invasives}

Aquatic invasive species (AIS) are species that are not native to a regional water body and moreover are unusually aggressive in colonizing a new area and causing damage to the environment or economy where they appear. There are many different non-native plant species found in the Great Lakes basin, but not all of them necessarily qualify as invasive. "The Great Lakes have...been troubled by fastgrowing invasive plants such as common reed (Phragmites australis), reed canary grass (Phalaris arundinacea), purple loosestrife (Lythrum salicaria), curly pondweed (Potamogeton crispus), Eurasian milfoil (Myriophyllum spicatum), frogbit (Hydrocharis morsus-ranae), and two types of non-native cattails (Typha angustifolia and Typha glauca)." ${ }^{177}$ These plants share typical invasive species characteristics, such as the ability to reproduce rapidly and colonize new ecological niches. ${ }^{178}$ One study found that, of the 278 species of plants found growing in 1980 near Lake Ontario, only 122 were native. ${ }^{179}$ Some plants are introduced deliberately, for example by nurseries for planting, and others are accidental releases into the environment. These complex vectors for introductions of AIS need further study to be fully understood. ${ }^{180}$

Some of these plant invaders take advantage of the damage already done to wetlands, marshes, and other coastal communities mentioned previously. Regulation of the lake levels of Lake Ontario, for example, changed the seasonal fluctuations that maintained the wetlands and provided an opportunity for invasive plant species to begin to take over. As the USGS Nearshore and Coastal Ecology center writes, AIS "became established in the wet soils above the water line, canopy-dominating larger plants such as cattails and purple loosestrife now crowd out other emergent plants in shallow water, and a few competitive submersed species dominate in slightly deeper water. Natural rejuvenation of wetland

\footnotetext{
${ }^{175}$ Ashworth at 124.

${ }^{176}$ Id.

${ }^{177}$ EPA, Great Lakes, Invasive Species, available at http://www.epa.gov/glnpo/invasive/, (last accessed May 2, 2013).

${ }^{178} \mathrm{Id}$.

${ }^{179}$ Grady, at 288.

${ }^{180}$ United States Environmental Protection Agency, United States Great Lakes Program Report on the Great Lakes Water Quality Agreement at 45.
} 
habitats has been lost..." ${ }^{\prime 181}$ Cattails in particular have become increasingly dominant in Great Lakes coastal lands. Dealing with the dense mats of cattails sometimes requires dredging to clear ponds and marshes for native species ${ }^{182}$ but dredging in turn disturbs sediments that may be holding toxic pollutants or excessive nutrients that then become available in the water column.

\section{ii. Invertebrate Aquatic Invasive Species}

Possibly the most infamous of the invasive species in the Great Lakes today are the zebra and quagga mussels (Dreissena polymorpha and Dreissena bugensis). These small mussels form large colonies on pipes, driftwood, pilings, and even other species, in numbers sufficient to overwhelm the surrounding space. These conglomerations have proven devastating to the ecology and economy of the Great Lakes. Environmental historian Jeff Alexander writes that in a single decade zebra mussels caused more than one and a half billion dollars worth of damages to municipal and industrial water systems, including shutting down the entire municipal water system of Monroe, Michigan in December $1989 .{ }^{183}$

Zebra mussels have complex effects on the ecology of the Great Lakes beyond simply forming physical conglomerations. The mussels filter feed on "microscopic algae from the water column, diverting nutrients from open water to lake bottom systems, thus favoring bottom-feeding fish (and their predators) over those such as alewife and smelt (and their predators) which feed in the open water. Aquatic rooted plants (macrophytes) and their communities (e.g. large mouth bass) thrive in water cleared by zebra mussel, while habitat is reduced for species adapted for turbid waters (e.g. walleye)." 184 The combination of zebra mussels and eutrophication in the Lakes leads to even more disruptions in the natural nutrient cycles that once maintained such large populations of native fish, as well as further events of hypoxia and toxic algal blooms. ${ }^{185}$ Zebra and quagga mussels also take in many pollutants that can harm other species who prey on them. ${ }^{186}$ Conversely, the zebra mussels can also play a part in sequestering nutrients into the benthic habitats instead of the water column, and may have helped mayfly larvae return to Lake Erie. ${ }^{187}$ Their overall effect, however, is generally disruptive to both the environment and the economy.

${ }^{181}$ Donald A. Wilcox, Effects of Lake Ontario Water-Level Regulation on Wetlands, USGS Great Lakes Science Center, available at http://www.glsc.usgs.gov/main.php?content=research_wetland_current_ontario\&title=Wetlands0\&menu =research_NCE_wetland.

${ }^{182}$ Michael L. Schummer, Jason Palframan, Emily McNaughton, Ted Barney, Scott A. Petrie, Comparisons of Bird, Aquatic Macroinvertebrate, and Plant Communities Among Dredged Ponds and Natural Wetland Habitats at Long Point, Lake Erie, Ontario, Wetlands, October 2012, Volume 32, Issue 5, pp 945-953.

${ }_{183}$ Jeff Alexander, Pandora's Locks, Michigan State University Press 2009, at xiii.

${ }^{184}$ United States Environmental Protection Agency, United States Great Lakes Program Report on the Great Lakes Water Quality Agreement at 43.

${ }^{185} \mathrm{Id}$.

${ }^{186}$ United States Department of Agriculture National Invasive Species Information Center, Quagga Mussel, available at http://www.invasivespeciesinfo.gov/aquatics/quagga.shtml.

${ }^{187}$ Alexander, at 365. 
Other invertebrate AIS include the spiny water flea (Bythotrephes longimanus) and the fishhook water flea (Cercopagis pengoi); recent invaders likely also brought in ballast water. These invaders are not insects as their common names suggest, but rather are a type of small crustacean. ${ }^{188}$ The EPA reports that the spiny water flea is a "tiny predatory crustacean that can reproduce both sexually and, more commonly, parthenogenically (without fertilization). This [has] allowed them to quickly populate Lake Ontario." ${ }^{189}$ Given their swift reproduction it is possible that these water fleas will profoundly alter the phytoplankton communities in the Lakes, and may further impact young fish by competing with them for microbiotic prey. ${ }^{190}$

\section{iii. Vertebrate Aquatic Invasive Species}

The Great Lakes are particularly prone to invasion biology, given that they are relatively young bodies of water (on a geologic time scale, anyway) and therefore have less overall biodiversity than older lakes. ${ }^{191}$ Other species, particularly those that reproduce quickly, can expand into empty or tenuous ecological niches. This is true at multiple trophic levels, even the largest niches occupied by dominant predator species. Environmental writer Grady notes that "before the settlement period there were 150 native fish species in the Great Lakes, nearly half of those have since declined or vanished, and 162 new, nonindigenous species have taken over their habitat". ${ }^{192}$

Like zebra mussels today, the "most wanted" of the Great Lakes invaders at the time of the original GLWQA was the sea lamprey (Petromyzon marinus). The parasitic sea lamprey looks somewhat like an eel but with a round sucker mouth that it uses to attach itself to large fish and consume blood and other bodily fluids. ${ }^{193}$ Sea lampreys moved up the Erie Canal in the mid 1800s into Lake Ontario and spread out into the basin ecosystem. ${ }^{194}$ Rising water temperatures and the opening of more connecting canals gave the lampreys pathways into the upper lakes. "By 1948, fishermen along the Michigan and Wisconsin coasts were reporting localized populations so large they roiled the surface of the water as they swamp about." ${ }^{\text {"95 }}$ These parasites had a devastating impact on the already stressed trout and whitefish populations.

The trophic cascade that resulted from the loss of the major predator fish that lived in the Lakes likely contributed to a second invasion: of a fish called the alewife (Alosa pseudoharengus). The alewives compete with native Lake herring (Coregonus artedi), chub, and juvenile whitefish for zooplankton. They have been breeding in the Great Lakes in huge numbers since the 1950s, with periodic die-offs in which

\footnotetext{
${ }^{188}$ USDA National Invasive Species Information Center, Spiny Water Flea and Fishhook Water Flea.

${ }^{189}$ EPA, Great Lakes, Invasive Species, available at http://www.epa.gov/glnpo/invasive/, (last accessed May 2, 2013).

${ }^{190}$ EPA, Great Lakes, Cercopagis pengoi, available at http://www.epa.gov/glnpo/monitoring/biology/exotics/cercopagis.html.

${ }^{191}$ Grady.

${ }^{192} I d$. at 289.

193 Ashworth at 114.

${ }^{194} \mathrm{Id}$.

${ }^{195}$ Id. at 119.
} 
bodies of alewives littered the beaches. ${ }^{196}$ Scientists in 1967 estimated that there were 167 billion alewives in Lake Michigan, enough to circle the Earth over 400 times laid end to end. ${ }^{197}$ The superabundance of prey fish like alewives and smelt lead fisheries managers to try to restock the Great Lakes with Pacific salmon. ${ }^{198}$ These commercially introduced fish in turn compete with the remaining lake and brook trout, as well as eating the young of other native species like sculpins, bloaters, and yellow perch. ${ }^{199}$ Other fish invaders include the round goby (Neogobius melanostomus), Eurasian ruffe (Gymnocephalus cernuus), and several species of carp. ${ }^{200}$

Attempts by the US and Canadian governments through the Great Lakes Fishery Commission to control the sea lamprey resulted in the development of a lampricide, TFM. ${ }^{201}$ This chlorinated compound was designed to kill young lamprey, while leaving native species unharmed. Unfortunately, TFM did have some toxic effects on native fish, mollusks, and amphibians, but the Fishery Commission appeared to consider this a small price to pay to reduce the vast population of sea lamprey. ${ }^{202}$ In the last few decades populations of sea lamprey have mostly been controlled, but not eradicated. ${ }^{203}$ The lampreys seem to have learned to hide from the control mechanisms in smaller streams and continue to breed at a rapid pace. $^{204}$

New potential invaders causing much concern in the Great Lakes community today are known as the Asian carp. There are four species of concern included in the term 'Asian carp': the bighead carp (Hypophthalmichthys nobilis), silver carp (Hypophthalmichthys molitrix), black carp (Mylopharyngodon piceus), and the grass carp (Ctenopharyngodon idella). ${ }^{205}$ The common European carp, an earlier invader, likely benefitted from the eutrophic status of some nearshore areas of the Lakes since they can survive on very little oxygen. ${ }^{206}$ The Asian carp have the potential to be even more detrimental than their European cousins. Asian carp also reproduce quickly, can grow very large, and pose a major threat to the current species diversity of Great Lakes fish if they ever actually make it into the Lakes. Major multijurisdictional efforts are underway to prevent exactly that scenario - Asian carp have already been found in the Chicago River and in the Wabash River, both of which have potential hydrological connections to the Great Lakes. ${ }^{207}$ Electric barriers have been installed by the US Army Corps of Engineers on the locks on the Chicago River to try to stop the carp from completing their journey into Lake Michigan, but that may not be enough. ${ }^{208}$

\footnotetext{
${ }^{196}$ Id. at 121.

${ }^{197}$ Alexander, at 60.

${ }^{198}$ Grady, at 297.

${ }^{199} I d$.

${ }^{200}$ EPA, Great Lakes, Invasive Species.

${ }^{201}$ Alexander, at 31.

${ }^{202}$ Id.; also Grady at 294.

${ }^{203}$ United States Environmental Protection Agency, United States Great Lakes Program Report on the Great Lakes Water Quality Agreement at 45.

${ }^{204}$ Grady, at 295.

${ }^{205}$ USDA National Invasive Species Information Center, Asian Carp.

${ }^{206}$ Grady, at 301.

${ }^{207}$ National Wildlife Federation, Asian Carp, available at http://www.nwf.org/Wildlife/Threats-toWildlife/Invasive-Species/Asian-Carp.aspx.

${ }^{208} I d$.
} 


\section{iv. Additional Future Invasives}

The current set of AIS was estimated in 2005 to be causing five billion dollars damage annually to the Great Lakes ecosystem and economy. ${ }^{209}$ Even if regulations prevented every new invasion in the future, we would still be facing an array of species that were not present in the Lakes ecosystem two hundred years ago, several of which have proven to cause economic and environmental damage. Unfortunately, that optimistic scenario is itself very unlikely.

Aside from the threat of Asian carp, other potential AIS could arrive at any time, and once they are in the ecosystem AIS are almost impossible to eradicate. The Great Lakes global shipping economy continues to be the most prevalent vector for invasive species. Each transoceanic ship could hold in its ballast tanks the next zebra mussel, the next new strain of cholera. In 2008 the U.S. and Canada began requiring ocean freighters to flush their ballast water tanks with ocean water before they entered the St. Lawrence Seaway and the Lakes. ${ }^{210}$ Although this is a good step, the mid-ocean ballast water exchange strategy is not one hundred percent effective, and further ballast water treatment technologies and ballast exchange regulations are under review. ${ }^{211}$

Preventing new invasives, and monitoring for those that do make it past current barriers to their entry, remains a major part of the binational management of the Great Lakes. Knowing how difficult it is to deal with any invasives that have had a chance to establish themselves, the Parties to the 2012 GLWQA have devoted much space in Annex 5 - Discharges from Vessels and Annex 6 - Aquatic Invasive Species to their prevention-based approach. The goals, in order of efficacy, are to prevent the introduction of AIS, control and reduce the spread of new or ongoing invasions, and to attempt to eradicate existing invaders. ${ }^{212}$

\footnotetext{
${ }^{209}$ David Pimentel, Aquatic Nuisance Species in the New York State Canal and Hudson River Systems and Great Lakes Basin: An Economic and Environmental Assessment, Environmental Management 35, 5, 692-701 (2005).

${ }^{210}$ Alexander at 372.

${ }^{211}$ Marine Invasions Research Lab, Mid Ocean Ballast Water Exchange, Smithsonian Environmental Research Center, available at http://www.serc.si.edu/labs/marine_invasions/vector_ecology/bw_exchange.aspx. 2122012 GLWQA, Annex 6 - Aquatic Invasive Species.
} 


\section{SECTION 3: COMPARISONS AND CONCLUSIONS}

There have been many ecological changes in the Great Lakes since the first GLWQA was signed in 1972, and the political and legal system that regulates it has sometimes struggled to keep pace. Will the 2012 GLWQA be successful in dealing with the most pressing environmental issues of the day? The following section compares the Agreement to the needs of the current Great Lakes ecosystem, and offers some insights to answer that question.

\section{A. Soft Law and Conflicting Management Strategies}

An interesting consideration of the GLWQA is whether or not it constitutes non-binding "soft law”. Soft law is voluntary international law without explicit deadlines or limits and without direct mechanisms for enforcement. It can be debatable, or simply difficult to tell, whether or not governments intend themselves to be bound by international law other than formal treaties, like an agreement or a protocol. "The main reason for this is that governments tend to be reluctant...to state explicitly in an agreement that it is nonbinding or lacks legal force. Consequently inferences as to such intent have to be drawn from the language of the instrument and the attendant circumstances of its conclusion and adoption.” ${ }^{213}$ Generally, these nonbinding agreements are written with language that expresses broad principles and general intentions, but lack specific goals and mechanisms for achievement. The language of the GLWQA contains provisions like these. For example, the language in Articles 3 and 4 of the 2012 Agreement reference the Parties "best efforts" to achieve the non-specific goals they have agreed on. The Purpose of the 2012 Agreement, like its predecessor Agreement of 1978, hedges with the language "the Parties agree to maximize their efforts to: (c) eliminate or reduce, to the maximum extent practicable, environmental threats to the Waters of the Great Lakes”. ${ }^{214}$ This language makes the tone of the Agreement sound even less binding - the Parties agree to do as much as is practicable to the extent they can. Such a soft law agreement could still induce the parties to take action towards the general goals, but failure to do so would probably not cause the other party or parties to take action against the nation in non-compliance. ${ }^{215}$ The Great Lakes is a two party commons, in this sense, with no higher regulatory authority in place to force either country to act against its own interests for the other, or for the good of the Lakes as an ecosystem.

The IJC could, potentially, mediate between the two nations in such a conflict under the aegis of the Boundary Waters Treaty. So far it has not operated in this manner. ${ }^{216}$ Given the lack of precedent otherwise - for instance, that no issue under the formal and binding Boundary Waters Treaty has been presented to the IJC commissioners for investigation and reporting - it does appear that these water quality agreements are more voluntary than they are binding "hard” international law. Article X of the Treaty only says that such disputes may be heard by the IJC, not that they must be. (See Section 1 discussion of this provision, supra.) Additionally, and unlike the Boundary Waters Treaty, the GLWQA

${ }^{213}$ Schachter, The Twilight Existence of Nonbinding International Agreements, 71 A.J.I.L. 296 (1977).

${ }^{214} 2012$ GLWQA, Article 2 (emphasis added).

${ }^{215} \mathrm{Id}$.

${ }^{216}$ See footnote 11. 
could be terminated by either side with only one year's notice. ${ }^{217}$ The confusion over what, precisely, the GLWQAs bind the party nations to actually do continues through all its amended versions, including the most recent 2012 agreement.

The U.S. and Canada do have disagreements on how best to manage the Great Lakes. Examples of this disagreement include the distinction drawn between chemicals acknowledged to be dangerous pollutants by both countries versus chemicals whose danger is advocated by only one country in the Binational Toxics Strategy. ${ }^{218}$ Differences in testing and determinations of levels of dangerous bacteria lead to mismatched beach closures and could confuse the public on critical safety issues. "The percentage of beaches closed more than ten percent of the season averaged nine percent in the United States and 42 percent in Canada during 2006-2007. Differences...may reflect differing posting criteria." ${ }^{, 19}$ Much language in the GLWQA reiterates the need for cooperation and collaboration between the U.S. and Canada, and the 2012 GLWQA adds even more focus on syncing up testing, standards, and monitoring. Annex 3 - Chemicals of Mutual Concern includes "coordinating the development and application of domestic water quality standards, objectives, criteria, and guidelines among the Parties...aligning, where appropriate domestic water quality standards”. ${ }^{220}$ Annex 4 - Nutrients maintains the specific and interim phosphorous load levels from the 1983 Supplement that apply to allocations from both countries. ${ }^{221}$ Annex 9 - Climate Change Impacts asks the Parties to "coordinate binational climate change science activities (including monitoring, modeling, and analysis) to quantify, understand, and share information that Great Lakes resource managers need to address climate change impacts”. ${ }^{222}$

Despite these disagreements, and the recognized need for an even closer partnership in the future, the two nations are mostly on the same page as far as Great Lakes ecological issues are concerned. Lacking any serious overt divergence in the Parties management strategies, it remains unclear how hard or soft - to put it another way, how ultimately enforceable - the GLWQA really is.

\section{B. New Priorities and Old Challenges}

As human activities have altered the Great Lakes biological, chemical, and hydrologic systems, new and complex ecological issues have arisen and the law of two countries has not always kept pace. In the new 2012 GLWQA revised legal methods aimed at new environmental issues (or new wrinkles in old issues) attempt to catch up.

The following is a chart of the history of environmental law and politics in the Great Lakes that may help to place the 2012 GLWQA in context. Legal and political issues are contrasted with the major ecological issues noted at the same time, and the central column considers the Great Lakes community of stakeholders and events that may have called attention to an environmental crisis or precipitated regulatory action. It is not fully comprehensive, of course, but does give a sense of the ongoing struggle to

${ }^{217}$ Botts \& Muldoon, supra, at 15.

${ }^{218}$ See Appendix 1 of the Strategy.

${ }^{219}$ 15th Biennial Report, at 28.

${ }^{220}$ Annex 3(B)

${ }^{221}$ Annex 4(C)

${ }^{222}$ Annex 9(C) 
keep politics abreast of the environmental issues. Many of these events have been discussed in previous sections. Items in bold are political actions like treaties or formal agreements.

Figure 3: History of the Great Lakes Environmental Evolution

\begin{tabular}{|c|c|c|c|}
\hline & $\begin{array}{l}\text { GLWQA and other } \\
\text { Legal/Political Events }\end{array}$ & GL Community Events & $\begin{array}{l}\text { Major Environmental } \\
\text { Issues }\end{array}$ \\
\hline 1615 & & $\begin{array}{l}\text { French explorer Samuel de } \\
\text { Champlain "discovers" } \\
\text { freshwater Lake Huron; } \\
\text { Iroquois Confederation at } \\
\text { its height. }\end{array}$ & \\
\hline 1774 & $\begin{array}{l}\text { Quebec Act limits British } \\
\text { settlement beyond expanded } \\
\text { borders of Quebec province }\end{array}$ & & \\
\hline 1780 & & $\begin{array}{l}\text { Beaver fur trade at its } \\
\text { height. }\end{array}$ & \\
\hline 1783 & $\begin{array}{l}\text { Treaty of Paris establishes } \\
\text { the border between British } \\
\text { and Colonial power through } \\
\text { the Great Lakes }\end{array}$ & & $\begin{array}{l}\text { Water consumption; over- } \\
\text { hunting and fishing; } \\
\text { navigation. }\end{array}$ \\
\hline 1814 & $\begin{array}{l}\text { Treaty of Ghent re- } \\
\text { establishes border between } \\
\text { British Canada and the } \\
\text { United States through the } \\
\text { Lakes }\end{array}$ & $\begin{array}{l}\text { Increasing settlement of } \\
\text { Great Lakes region }\end{array}$ & \\
\hline 1825 & & Erie Canal opens. & \\
\hline $\begin{array}{l}\text { 1840s- } \\
1890 s\end{array}$ & & $\begin{array}{l}\text { Logging and timber } \\
\text { production at its height. }\end{array}$ & $\begin{array}{l}\text { Deforestation; erosion; } \\
\text { hypoxia from bark and } \\
\text { sawdust dumping. }\end{array}$ \\
\hline 1840s & & $\begin{array}{l}\text { Major mining operations } \\
\text { for iron, copper, and nickel } \\
\text { expand. }\end{array}$ & $\begin{array}{l}\text { Pollution from ore extraction } \\
\text { and refining. }\end{array}$ \\
\hline 1896 & & & $\begin{array}{l}\text { Last Atlantic salmon reported } \\
\text { in Lake Ontario. }\end{array}$ \\
\hline 1900 & & $\begin{array}{l}\text { Chicago wastewater project } \\
\text { reverses flow of Chicago } \\
\text { River out of Lake } \\
\text { Michigan. }\end{array}$ & $\begin{array}{l}\text { Bacterial pollution and } \\
\text { human disease from sewage; } \\
\text { diversion of water out of the } \\
\text { Lakes. }\end{array}$ \\
\hline 1905 & $\begin{array}{l}\text { International Waterways } \\
\text { Commission established to } \\
\text { study and report on water. }\end{array}$ & & $\begin{array}{l}\text { Water consumption; } \\
\text { pollution. }\end{array}$ \\
\hline 1909 & $\begin{array}{l}\text { Boundary Waters Treaty } \\
\text { signed. }\end{array}$ & & \\
\hline
\end{tabular}




\begin{tabular}{|c|c|c|c|}
\hline 1918 & $\begin{array}{l}\text { First IJC Report on } \\
\text { Reference Great Lakes } \\
\text { Pollution submitted; Proposal } \\
\text { for pollution agreement for } \\
\text { IJC. }\end{array}$ & & $\begin{array}{l}\text { Water consumption; } \\
\text { pollution. }\end{array}$ \\
\hline $\begin{array}{l}\text { 1930s- } \\
1940 s\end{array}$ & & & $\begin{array}{l}\text { Sea lampreys invade the } \\
\text { Great Lakes. }\end{array}$ \\
\hline 1946 & $\begin{array}{l}\text { Report of the International } \\
\text { Joint Commission on the } \\
\text { Pollution of Boundary } \\
\text { Waters Reference from } 1946 .\end{array}$ & & $\begin{array}{l}\text { Bacterial pollution; water } \\
\text { pollution (phenols, oil, iron, } \\
\text { phosphorous, chloride); } \\
\text { navigation. }\end{array}$ \\
\hline 1959 & & $\begin{array}{l}\text { St. Lawrence Seaway } \\
\text { opens. }\end{array}$ & \\
\hline 1963 & & $\begin{array}{l}\text { Publication of "Silent } \\
\text { Spring" by Rachel Carson. }\end{array}$ & $\begin{array}{l}\text { Reproductive failures in fish- } \\
\text { eating birds in Great Lakes } \\
\text { region. }\end{array}$ \\
\hline 1967 & & $\begin{array}{l}\text { Media reports Lake Erie is } \\
\text { "dying". }\end{array}$ & $\begin{array}{l}\text { Nutrient pollution, hypoxia, } \\
\text { and the formation of dead } \\
\text { zones. }\end{array}$ \\
\hline 1969 & & $\begin{array}{l}\text { Cuyahoga River catches } \\
\text { fire. }\end{array}$ & Oil and gas pollution. \\
\hline 1970 & $\begin{array}{l}\text { Creation of US } \\
\text { Environmental Protection } \\
\text { Agency. }\end{array}$ & & \\
\hline 1971 & $\begin{array}{l}\text { Creation of Canadian } \\
\text { Department of the } \\
\text { Environment. }\end{array}$ & & $\begin{array}{l}\text { Consumption warnings } \\
\text { issued for Great Lakes fish } \\
\text { based on mercury } \\
\text { contamination. }\end{array}$ \\
\hline 1972 & First GLWQA signed. & & $\begin{array}{l}\text { Municipal and industrial } \\
\text { pollution, primarily of } \\
\text { phosphorous and bacteria. } \\
\text { Some discussion of toxics. }\end{array}$ \\
\hline 1976 & & $\begin{array}{l}\text { Love Canal becomes a } \\
\text { major news story about } \\
\text { toxic pollution. Pollutants } \\
\text { from Love Canal and other } \\
\text { dump sites drain into the } \\
\text { Niagara River and } \\
\text { ultimately into Lake } \\
\text { Ontario. }\end{array}$ & \\
\hline 1978 & Renewal of the GLWQA. & $\begin{array}{l}\text { President Carter declares } \\
\text { Love Canal a federal } \\
\text { disaster area. }\end{array}$ & $\begin{array}{l}\text { Toxic chemicals and other } \\
\text { hazardous substances, } \\
\text { particularly PCBs and } \\
\text { insecticides, are found } \\
\text { polluting the Lakes. }\end{array}$ \\
\hline 1983 & GLWQA amended. & & $\begin{array}{l}\text { Renewed focus on } \\
\text { phosphorous pollution. }\end{array}$ \\
\hline 1985 & $\begin{array}{l}\text { Great Lakes Charter signed } \\
\text { by states and provinces. }\end{array}$ & & $\begin{array}{l}\text { Concern about possible } \\
\text { diversions of water out of the }\end{array}$ \\
\hline
\end{tabular}




\begin{tabular}{|c|c|c|c|}
\hline & & & Great Lakes basin. \\
\hline 1986 & $\begin{array}{l}\text { Governors of Great Lakes } \\
\text { states sign Great Lakes } \\
\text { Toxic Substances Control } \\
\text { Agreement, joined by } \\
\text { provinces in additional } \\
\text { memorandum. }\end{array}$ & & $\begin{array}{l}\text { Multiple sources of multiple } \\
\text { toxic chemicals in Great } \\
\text { Lakes basin. }\end{array}$ \\
\hline 1987 & $\begin{array}{l}\text { GLWQA amended by an } \\
\text { additional Protocol. }\end{array}$ & & $\begin{array}{l}\text { Pollution from non-point } \\
\text { sources, including rural and } \\
\text { urban runoff and airborne } \\
\text { toxic pollutants. Zebra } \\
\text { mussels invade the Lakes. }\end{array}$ \\
\hline 1989 & & $\begin{array}{l}\text { A clog of zebra mussels } \\
\text { shuts down the municipal } \\
\text { water intake of Monroe, } \\
\text { Michigan. }\end{array}$ & \\
\hline 1991 & $\begin{array}{l}\text { Canada and the U.S. sign Air } \\
\text { Quality Agreement. }\end{array}$ & & \\
\hline 1994 & $\begin{array}{l}\text { First Area of Concern in the } \\
\text { Great Lakes is restored and } \\
\text { de-listed. }\end{array}$ & & \\
\hline 1995 & & $\begin{array}{l}\text { 25th Anniversary of Earth } \\
\text { Day }\end{array}$ & \\
\hline 1997 & $\begin{array}{l}\text { Canada and the U.S. sign } \\
\text { Great Lakes Binational } \\
\text { Toxics Strategy. }\end{array}$ & & $\begin{array}{l}\text { Ongoing concerns about toxic } \\
\text { pollutants, particularly for } \\
\text { children and pregnant } \\
\text { women. }\end{array}$ \\
\hline 2000 & & $\begin{array}{l}\text { E. coli outbreak in } \\
\text { Walkerton, Ontario, after } \\
\text { heavy rainfall sickens } \\
\text { thousands and kills seven. }\end{array}$ & \\
\hline 2001 & $\begin{array}{l}\text { Governors of Great Lakes } \\
\text { states sign Annex 2001, an } \\
\text { update to the Charter. }\end{array}$ & & \\
\hline 2002 & $\begin{array}{l}\text { Great Lakes Legacy Act } \\
\text { passed by U.S. Congress. }\end{array}$ & & $\begin{array}{l}\text { Asian carp discovered in the } \\
\text { Illinois River } 50 \text { miles from } \\
\text { Lake Michigan. }\end{array}$ \\
\hline 2004 & $\begin{array}{l}\text { Executive order by President } \\
\text { Obama creates Great Lakes } \\
\text { Interagency Task Force. }\end{array}$ & $\begin{array}{l}\text { Great Lakes environmental } \\
\text { advocacy groups form the } \\
\text { Healing Our Waters } \\
\text { Project. }\end{array}$ & \\
\hline 2005 & & $\begin{array}{l}\text { 1,500 stakeholders } \\
\text { contribute to the Great } \\
\text { Lakes Regional } \\
\text { Collaboration Strategy }\end{array}$ & \\
\hline
\end{tabular}




\begin{tabular}{|l|l|l|l|}
\hline 2008 & $\begin{array}{l}\text { International Maritime } \\
\text { Organization establishes } \\
\text { ballast water treatment } \\
\text { guidelines. }\end{array}$ & & \\
\hline 2010 & $\begin{array}{l}\text { Great Lakes Restoration } \\
\text { Initiative begins (will run } \\
\text { until 2014). }\end{array}$ & & $\begin{array}{l}\text { Toxics, invasive species, } \\
\text { nearshore health, habitat loss, } \\
\text { and monitoring. }\end{array}$ \\
\hline 2011 & & $\begin{array}{l}\text { Record-breaking new algal } \\
\text { blooms appear in Lake } \\
\text { Erie, garnering new media } \\
\text { attention. }\end{array}$ & \\
\hline 2012 & GLWQA amended. & & $\begin{array}{l}\text { Lakes Huron and Michigan } \\
\text { hit the lowest water levels } \\
\text { ever recorded. }\end{array}$ \\
\hline 2013 & & & \\
\hline
\end{tabular}

As can be seen in the history chart, many issues in the Great Lakes have appeared, lessened, and reappeared in new forms with new and baffling twists. Phosphorus loading and associated algal blooms are one of the most notable problems in this respect, having been "solved" and yet re-occurring in even more dramatic fashion in recent years. A record breaking "mega-bloom” in Lake Erie in 2011 drew media attention to the reappearance of this problem, as well as its likely connection to newer issues of climate change and the presence of invasive zebra and quagga mussels. ${ }^{223}$ The new Annex 4 - Nutrients distinguishes Lake Erie in its Lake Ecosystem Objectives as being generally mesotrophic, and sets more specific goals for managing nutrient loading into this warmer and shallower basin. ${ }^{224}$ Despite having phosphorous controls as a priority for more than twenty five years, eutrophication in Lake Erie continues to be a serious issue today.

There are also several elements in the GLWQA that address wholly new problems. Perhaps the most interesting of these in the 2012 GLWQA is Annex 9 - Climate Change Impacts (See Section 1, supra). Canada and the U.S. have had political disagreements over climate change in the past. U.S. President George Bush's refusal to join the Kyoto protocol in 2001 is believed to have lead Canada to ultimately pull out of the climate change agreement in $2011 .{ }^{225}$ With the two countries somewhat more in sync now, politically and scientifically, on this issue, climate change has finally made an appearance in the GLWQA. To sum up, “[a] very significant change in the Great Lakes Basin is predicted to occur over the next 100 years as a result of global warming. The amount of carbon dioxide has been increasing, now

${ }^{223}$ See, e.g., John Mangels, Record-sized Lake Erie algae bloom of 2011 may become regular occurrence, study says, The Cleveland Plain Dealer, April 01, 2013 at 3:00 PM, available at http://www.cleveland.com/science/index.ssf/2013/04/record-sized lake erie algae b.html, (last accessed April 20, 2013); Dean Praetorius, Lake Erie's Toxic Algae Bloom Seen From Space: Green Scum Rampant In The Great Lakes, Huffington Post, First Posted: 10/14/11 05:16 PM ET, Updated: 12/14/11 05:12 AM ET, available at http://www.huffingtonpost.com/2011/10/14/lake-eries-toxic-algaebloom n 1010902.html, (last accessed April 20, 2013).

${ }^{224}$ E.g., Annex 4 - Nutrients B(6) and D(6).

${ }^{225}$ See, e.g. David Ljunggren, Analysis: Canada's Kyoto withdrawal began when Bush bolted, Reuters, 12-13-2011, available at http://www.reuters.com/article/2011/12/13/us-kyoto-withdrawalidUSTRE7BB1X420111213. 
exponentially, for the past 200 years. Various mathematical models predict that if carbon dioxide levels rise to twice normal levels, the temperature in the Great Lakes Basin will rise by $2.5-4.0{ }^{\circ} \mathrm{C}$. This will result in increased evaporation and reduced precipitation, causing problems for shipping (lower water levels and increased dredging), industrial and municipal water intakes, loss of nearshore habitats, disappearance of inland habitats, loss of many native species, an influx of new species able to tolerate the new conditions, and possibly new diseases." ${ }^{226}$ These constitute major threats to the maintenance of Lake ecosystems and water quality. However, it should be noted that the language of Annex 9 discusses only the ultimate effects of climate change on the Great Lakes. It has no language discussing the two countries' larger struggle to mitigate greenhouse gas emissions. This can be contrasted with the language in Annex 3 - Chemicals of Mutual Concern that notes that the Public can help to achieve environmental protection goals by using fewer chemicals embracing green chemistry alternatives. Annex 9 seems to be a step in the right direction - at least both countries are now discussing global warming openly - but it does not have the same comprehensive tone as some of the other older and better known issues.

The ecosystem approach, expanded in the 2012 Agreement, now incorporates more territory and more potential issues under the broad umbrella of the GLWQA. The additions of groundwater and atmospheric pollution have significantly expanded the scope - at least on paper - beyond the initial bounds of the foundational Boundary Waters Treaty (a one sentence obligation not to pollute the boundary waters themselves). Ecologically and hydrologically this makes sense; it is a recognition that water, species, chemicals, and energy in such a large system move freely across legal jurisdictions. The language of the Preamble acknowledges that pollutants, for example, "may enter the Waters of the Great Lakes from air, surface water, groundwater, sediment, runoff from non-point sources, direct discharges and other sources". However, it is unclear how far this broad view will be taken in actual management. Returning to the question of Annex 9 - Climate Change, adaptation to the effects of climate change could be undertaken on multiple scales, from local to binational. Mitigation efforts, on the other hand, would require international action on the largest scale. And yet, the emission of greenhouse gasses around the world is clearly a contributor to some of the problems identified as impairing lake ecosystems. These issues are connected to global changes beyond the watersheds of the Lakes themselves and beyond the jurisdictions of the two Party countries. If the GLWQA does not reach so far, how should the Parties act to fulfill their obligations under the Agreement?

Scientific knowledge has advanced, and the political atmosphere changed considerably, since the last time the GLWQA was renegotiated in 1987. The previous GLWQAs have recorded some great accomplishments, and yet continued to struggle with the same issues over and over again. Like PCBs in the sediment, or zebra mussels on the bottomlands, these problems are very difficult to understand and manage. This new GLWQA has made significant advances on paper. It remains to be seen if the Parties, and the other stakeholders, will use the opportunity to make significant improvements in the Lakes.

\footnotetext{
${ }^{226}$ Harvey Shear, The Great Lakes, An Ecosystem Rehabilitated, but Still Under Threat, Environmental Monitoring and Assessment, 113: 199-225 (2006).
} 


\section{CONCLUSION:}

Consider, if you will, the following metaphor: Picture the Great Lakes as a map laid out before you. Detailed on this map are all the ecological issues, vectors, and environmental hotspots in the Lakes that require intervention and management. They are complex and interconnected. The laws and policies are like jigsaw puzzle pieces placed on top of the map. Some are large and cover multiple issues; some are small and cover only a local, targeted problem. But this is a poorly made puzzle, not all of the pieces fit together. It is a jigsaw by committee. A few of the ecological issues on the map are covered by multiple pieces of law and policy and it is unclear which should be used to cover them. A more critical problem, however, are the places where there are still no pieces which fit, creating gaps, some small, some large. This is a simple mental image of how all the varied laws and policies which attempt to address environmental issues in the Great Lakes sometimes fail to cover critical areas.

The GLWQA, and the IJC as a top-level bilateral organization, was intended to help fix this problem by coordinating management of the Great Lakes ecological issues between multiple state, provincial, local, and federal governments. They needed less overlap, and more importantly, to cover the remaining gaps in the law and policy where an issue might go unaddressed. This is a large and complicated task. A comprehensive GLWQA tries to address all the issues and coordinate the multiplicity of agencies and organizations so that everything can be managed. The GLWQA does not, itself, deal with the issues in a very practical way. Its potential strength is the ability to see the whole picture at once and help all the other smaller pieces to line up in a coordinated way. In that sense, the GLWQA is most successful when it is broadest: including the maximum amount of stakeholder concerns and ecological issues, with the simplest pattern of organization control, jurisdiction, and management. It is unsuccessful when the various agencies move on their own, doubling up on issues and complicating each other's actions, or missing critical new trouble spots entirely.

The new 2012 GLWQA has the potential to be an excellent guide for the coordination of action on the current list of ecological issues threatening the Great Lakes. The annexes are simple but broad, with multiple similar issues now collected into single topics. The ecological and watershed management approaches are comprehensive and reflect the best science of the day. They attempt to deal with, on a broader scale than in any of the previous GLWQAs, to deal with the Lakes as an interconnected hydrologic system including groundwater, the watershed, and even global atmospheric pollution (deposition of chemicals and climate change). However, the GLWQA is like the picture of the metaphorical puzzle on the puzzle's box; it is only shows what the completed puzzle has the potential to become. It is up to all of the independent pieces to fill in the gaps for complete coverage of the issues. If the actual puzzle is never wholly put together, the picture on the box is less than useful. If the agencies and organizations of the Great Lakes do not address, in a comprehensive and coordinated manner, all of the complex ecological problems at play, then it doesn't matter how good or comprehensive or scientifically accurate the new Agreement is. It is a tool and if it goes unused then no one can judge how useful it really is in the abstract. The GLWQA is only as good as the myriad agents in the lakes decide it will be. The opening language of the 2012 Agreement states that it was written to "update and strengthen” the 1978 Agreement. ${ }^{227}$ Updated - particularly in the inclusion of new scientific complexity - it certainly has been. Whether or not the Agreement has been strengthened - in terms of requiring more substantive

2272012 GLWQA, Amending Protocol. 
management action or even binational coordination - is more open to debate. The ultimate efficacy of the Agreement, perhaps, can only be determined in hindsight - maybe as the next Agreement is being considered. 